\title{
HAPPINESS AND VIRTUE IN SOCRATES' MORAL THEORY'
}

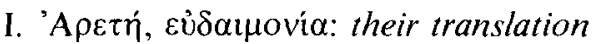

The key terms in my title pose problems of translation with which I can only deal in the most cursory manner. On 'virtue' for $\alpha \rho \varepsilon \tau \eta \dot{~ I ~ n e e d ~ n o t ~ l i n g e r ~ a t ~ a l l, ~ f o r ~}$

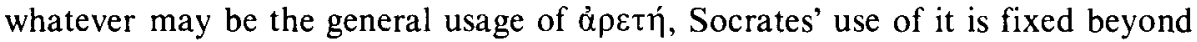
doubt by the fact that whenever he brings the general concept under scrutiny - as when he debates its teachability in the Protagoras and the $\mathrm{Meno}^{2}$ - he assumes without argument that its sole ${ }^{3}$ constituents or 'parts' $\left(\mu o ́ p l \alpha,{ }^{4} \mu \varepsilon \eta^{5} \eta^{5}\right)$ are five qualities which are, incontestably, the Greek terms of moral commendation par

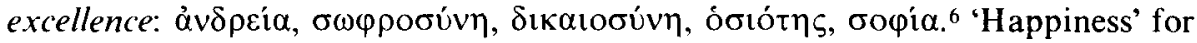

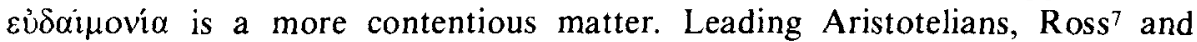
Ackrill, ${ }^{8}$ have claimed that 'well-being' would be a better translation. But in their own translations of the E.N. both' stick to 'happiness' all the same. It is not hard to see why they would and should. 'Well-being' has no adjectival or adverbial forms. This may seem a small matter to armchair translators - philosophers dogmatizing on how others should do the job. Not so if one is struggling with its nitty gritty, trying for clause-by-clause English counterparts that might be faithful to the sentence-structure, no less than the sense, of the Greek original. And 'well-being' suffers from a further liability: it is a stiff, bookish phrase, bereft of the ease and grace with which the living words of a natural language perform in a wide diversity

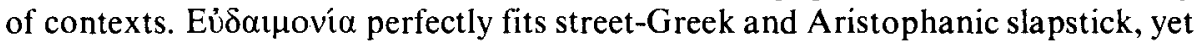
also, no less perfectly, the most exalted passages of tragedy. Even ecstasy is not beyond its reach, as in the cult-hymn in the Bacchae,

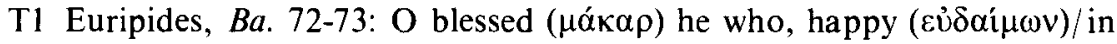
knowing the rites of the gods/lives in holiness,

and the epiphany in the Phaedrus,

T2 Plato, Phdr. 250 b-c: Radiant beauty was there to see, when with the

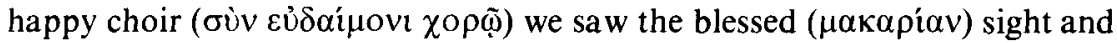
vision and celebrated that rite which, with all due reverence, we may call most blessed of all. ${ }^{10}$

Ev̉ $\delta \alpha^{i} \mu \omega v$ reaches easily the highest registers of intensity, keeping pace with $\mu \alpha \alpha^{\prime} \alpha \rho$, $\mu \alpha \kappa \alpha \operatorname{\alpha io}$, matching their tonality and resonance, evoking so marvellous a felicity 
that the gods themselves could ask for nothing better for themselves ${ }^{11}$ and we in turn could ask no greater gift from them:

T3 Arist. E.N. 109b11-13: If there is any gift from gods to men, it is reasonable that $\varepsilon \dot{\delta} \delta \alpha \mu$ ovía should be god-given. Of all things human this is most fit to be god-given, for it is the best.

What then, really, is the objection to 'happiness' for $\varepsilon v 3 \delta \alpha \mu$ ovia? What is there about the meaning of the English word which is supposed to make it a mismatch for the Greek one? Consider what our dictionaries make of 'happiness':

T4 O.E.D. (second of three entries, the only relevant one): the state of pleasurable content of mind which results from success or the attainment of what is considered good.

Webster's: a state of well-being and pleasurable satisfaction.

Two features of the concept are recognized in both: a subjective (pleasurable contentment or satisfaction) and an objective one (attainment of good, well-being). But whereas in the O.E.D. happiness is identified with the first, only causally connected with the second (it is the pleasurable mental state, it results from attainment of what is considered good), in Webster's the two factors are conjunctive, on a par. Now consider the standard objection to "happiness' for

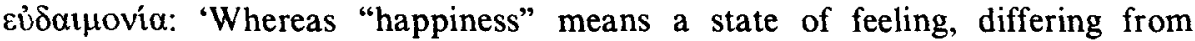
"pleasure" only by its suggestion of permanence, depth, and serenity, Aristotle

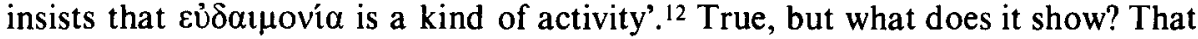

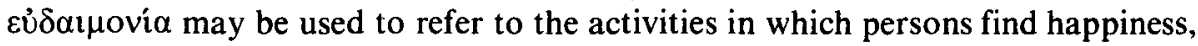
not that it must be so used. That it need not should be clear from the fact that the Greek hedonists have no difficulty in calling what they consider the good for man

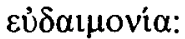

T5 Epicurus ap. Diogenes Laertius 10.122: We must study the things which

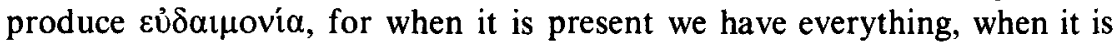
absent we do everything to obtain it.

But while for Aristotle this end is an activity, for Epicurus it is pleasure and the absence of pain. Thus if hedonism is a mistake, having $\varepsilon v \delta \delta \imath \mu o v i \alpha$ as your word for

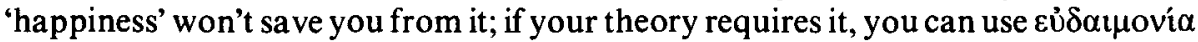
to mean pretty much what the O.E.D. takes 'happiness' to mean. If Aristotle's

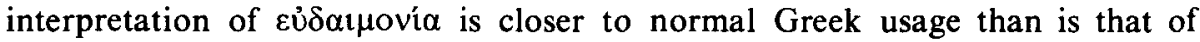

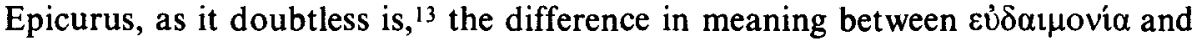
'happiness' in their normal use would still be no greater than that between alternative definitions of 'happiness' in major English dictionaries. This is ample reason for sticking to the traditional translation, provided only we bear in mind that in its pre-theoretical uses $\varepsilon \dot{\delta} \delta \alpha \mu$ ovi $\alpha$ puts a heavier loading on the objective factor in 'happiness' than does the English word. 


\section{The three positions on Eudaemonism}

I may now introduce the principle, frequently termed 'eudaemonism', which, once staked out by Socrates, becomes axiomatic for all subsequent moralists of classical antiquity. This is that happiness is desired by all human beings as the ultimate end ( $\tau \dot{\varepsilon} \lambda \mathrm{O})$ ) of all their rational acts. ${ }^{14}$ The best clue to what this means is in a remark in Plato which every Greek moralist would applaud:

T6 Plato, Symposium 205a2-3: Of one who wants to be happy there is no longer any point in asking, 'Why (iv $\alpha \tau \imath$ ) does he want to be happy?' There, it seems, the question stops.

In the imaginary dialogue $A$ asks $B$, 'Why do you want $x$ ?' and if $B$ replies, 'Because it will get me $y$ ', $A$ persists until the point is reached where $B$ replies, 'Because it will make me happy' and then 'the question stops': to renew it after that would be pointless. Thus to say that happiness is 'the $\tau \dot{\varepsilon} \lambda$ o $\zeta$ of all our actions'Is is not to say that this is what we are always, or often, thinking of when choosing what to do in our daily life, but only that this is the last reason we could give if pressed to give our reason for choosing to do anything at all - the only one which, if given, would make it senseless to be asked for any further reason. ${ }^{16}$

This being the case, the question, 'Why should I be moral?' which some modern moralists would find tendentious - perversely predicated on the reduction of morality to interest ${ }^{17}$ - is for all Greek moralists a perfectly proper and unavoidable one, the most urgent of all the questions they must confront. It is on just this issue that they divide. They agree that the right reply is 'Because moral conduct offers me best prospects for happiness.' They disagree on the reason why this is so: they differ radically among themselves on the relation of virtue to happiness:

(1) For some the relation is purely instrumental: they hold that virtue is desirable only as an instrumental means to happiness, not at all for its own sake.

(2) For others the relation is constitutive, but only partly so; they hold that virtue is a principal, but not the only, thing desirable for its own sake.

(3) For still others, who go further in the same direction, the relation is constitutive in toto; for them virtue is happiness - the only thing that makes life good and satisfying.

Position (1) is held by one of Socrates' own intimate companions, Aristippus, ${ }^{18}$ and, after him, by Epicurus and his many followers. Identifying happiness with pleasure and the absence of pain, they hold that virtue should be preferred to vice because, and only because, it is the more likely of the two to yield hedonic benefit. This identification of happiness (or 'the good') ${ }^{19}$ with pleasure Socrates attacks in the strongest terms in the Gorgias. He argues that it could ${ }^{20}$ sanction a life of obscene self-indulgence - the life of a catamite (494E). Since the moral theory I shall be exploring in this paper is precisely the one Socrates holds in the Gorgias ${ }^{21}$ 
(consistently with what he says in every Socratic dialogue) ${ }^{22}$ in opposition to the identification of the good with pleasure, ${ }^{23}$ we must conclude that whatever else Socrates may or may not have been, he certainly was no hedonist.

Position (2) is Aristotle's and Plato's. It has taken philosophical scholarship some time to catch up with this fact. Half a century ago leading lights in Oxford were strongly inclined to believe, and some of them did believe, that if Plato and Aristotle were eudaemonists they would have had to be utilitarians: H. A. Pritchard, a stubborn Kantian, so argued with conviction. ${ }^{24}$ What he and others had failed to understand is how it was possible for Plato and Aristotle to hold that every action is chosen for the sake of happiness and that some actions are chosen for their own sake, which is, of course, what Aristotle says in so many words:

T7 E.N. 1097b1-5: [Happiness] we choose always for itself, never for the sake of anything else. But honour, pleasure, intelligence, and every virtue we choose indeed for themselves - for if nothing resulted from them, we would still choose each of them - but we choose them also for the sake of happiness.

Can Aristotle hold without inconsistency that something can be desired for its own sake and also for the sake of something else? He certainly can, and if so fine an Aristotelian as Ross had failed to see this, ${ }^{25}$ it was only because, bullied by prevailing philosophical dogmas, he had not paid due attention to the fact that for Aristotle happiness consists of goods like those named in $\mathrm{T} 7$ - is nothing but such goods:

T8 Magna Moralia 1184a26-9: For happiness is composed of certain goods. For it is not something other than these, distinct from them: it is these (ì $\gamma a ̀ \rho$

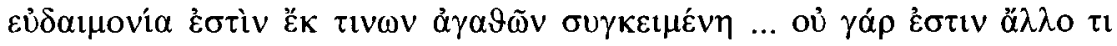

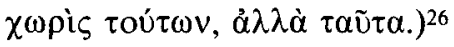

Scruples over the authenticity of the Magna Moralia ${ }^{27}$ could, conceivably, have kept Ross from taking this text seriously. However, he could have got the same message from a passage in the $E . N$. which, long before, had been understood and glossed correctly:

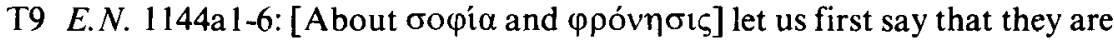
choiceworthy for their own sake - as they would have to be ... even if neither of them produced anything, for they are virtues. But then [let us observe] that they do produce something, though not in the way in which medicine produces health: бopia produces happiness in the way health does. ${ }^{28}$ For being a part ( $\mu \dot{\varepsilon} \rho \rho)$ of complete virtue it makes one happy by being possessed and exercised. ${ }^{29}$

As Stewart ${ }^{30}$ and Greenwood ${ }^{31}$ saw, here we are told how certain things can be desirable both for their own sake and for the sake of happiness: because they are 'component parts' (Greenwood), 'constituent elements' (Stewart) of the happiness 
they are said to 'produce'.

Is there any difficulty in understanding such a relation? Suppose I am very fond of the andante of a Beethoven symphony. If this had been the only part of it that had survived, I would play it 'for its own sake'. But luckily enough I do have the whole symphony and I treasure all of it. So when I listen to the andante I do so both for its own sake and for the sake of the whole ordered sequence of movements to which it belongs. This is how Aristotle thinks of the relation of virtue to happiness, ${ }^{32}$ except that the relation he has in view is multidimensional and synchronic, as well as diachronic, and virtue is only one of the 'parts' of happiness, each of which may be desired both for its own sake and for the sake of the whole. Thus consider the case of temperance. If we follow Aristotle we should choose to be temperate both for its

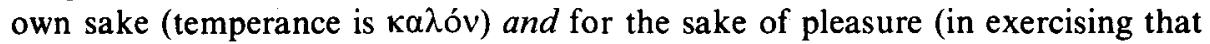
virtue we get a special pleasure which we could get in no other way) and for the sake of health (temperate indulgence in food and drink is integral to health) and for the sake of honour (if we live among morally sensitive people we win their esteem by our temperance) and for the sake of happiness which consists of all these 'parts' of it and of many more besides. ${ }^{33}$

Plato's view of happiness in Republic 2-10 and the Philebus is not expounded as fully or as explicitly as in the works of Aristotle. Unlike the latter, Plato never uses the 'parts/whole' terminology for the relation of intrinsically valuable goods to happiness. Nor does he speak of them as being desired both for their own sake and for the sake of happiness. I shall not undertake to argue here that nonetheless what Plato does say can be put together in a pattern substantially like the one in Aristotle. What is essential for my purpose is sufficiently indicated in the trichotomy of goods with which Glaucon begins his speech in Rep. 2 (357b-358a):

(a) Goods desirable for their own sake. Example: harmless pleasure.

(b) Goods desirable both for their own sake and for their consequences. Examples: thinking, seeing, health; justice (and, by implication, all the virtues).

(c) Goods desirable only for their consequences. Examples: physical training, medical treatment, money-making.

Since the goods in class (c) are desirable only for the sake of those in classes (a) and (b), all those whose possession will make us happy must fall into those two classes. So each of the goods in (a) and (b) must be components of happiness, for this is the only way in which they could be desired both for their own sake (as they are said to be) and for the sake of happiness (as they must be, for as we saw in T6 above, happiness is 'the question-stopper' - the final reason why anything is desired, hence why pleasure, health, thinking, virtue or anything else is desired.)

Position (3), the view that virtue is the only constituent of happiness - that virtue is happiness, the whole of it - is held by that strange man, Antisthenes, the progenitor of Cynicism, who was one of Socrates' closest friends and associates, ${ }^{34}$ 
and was later held not only by the Cynics - the philosophical hippies of classical antiquity - but also by that incomparably more numerous and ultra-respectable philosophical sect, the Stoics. ${ }^{35}$ Of the content of Antisthenes' doctrine we know all too little. But its general tenor is indicated by the saying attributed to him by

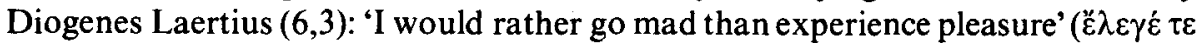

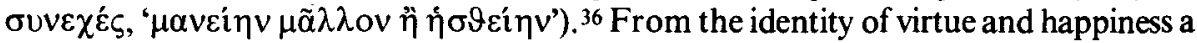
eudaemonist would unavoidably infer that all non-moral goods were, at best, matters of indifference. Could this be Socrates' view of the relation of virtue to happiness?

I believe that the best attack on this question can be made from a central principle of Socrates' practical moral teaching which I shall call, for reasons to be explained directly, the 'Sovereignty of Virtue'. Though this makes no reference to happiness as such, it nonetheless gives us our best insight into the problem. Here we can best see how Socrates, in his total innocence of the problematik not only of modern moral theory but even of Hellenistic and Greco-Roman philosophical ethics, approaches the matter. For this purpose I shall begin with three thoroughly familiar, yet sadly neglected ${ }^{37}$ passages, two of them in the Apology, the third in the Crito, where Socrates declares the Sovereignty of Virtue his supreme principle of practical choice. The third is particularly illuminating, for it reveals the structural design of the fundamentals of Socrates' moral theory: its content shows how he gets to that principle and what he can get from it.

\section{Socrates' principle of the Sovereignty of Virtue}

He states it twice over in the Apology, invoking it to explain why he had followed for so many years that singular course of conduct which has now put him in peril of his life. If someone were to reproach him for that, he says, this would be his reply:

T10 Ap. 28b5-9: You don't speak well, my man, if you believe that a man

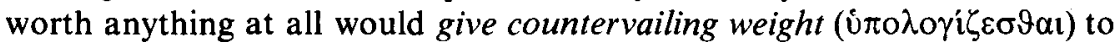
danger of life or death, instead of considering only this when he acts: whether his action is just or unjust, the action of a good or of an evil man.

He reiterates the principle a few lines later, using again the verb I am translating 'give countervailing weight'; for, as Riddell points out, ${ }^{38}$ what is conveyed by i $\pi 0-$ in i $\pi \circ \lambda \circ \gamma_{i} \zeta \varepsilon \sigma \vartheta \alpha l$ is not subtraction but rather, as he puts it, 'meeting from an opposite direction' - as in i $\pi \alpha v \tau \tilde{\alpha} v$, $\dot{\delta} \pi \omega \mu \circ \sigma^{\prime} \alpha$, 'affidavit to stop proceedings',

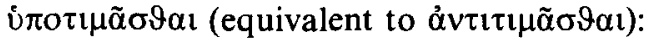

T11 Ap. 28d6-10: This is the truth of the matter, men of Athens: Wherever a man posts himself on his own conviction that this is best or on orders from his commander, there, I do believe, he should remain, giving no countervailing weight $(\mu \eta \delta \dot{\varepsilon} v$ i $\pi \mathrm{o} \lambda \mathrm{\gamma} \gamma \mathrm{\zeta} \zeta \mathrm{o} \mu \varepsilon v o v)$ to death or to anything else when the alternative is to act basely ( $\pi \rho$ ò toũ $\alpha i \sigma \chi \rho \circ \tilde{)}) .{ }^{39}$ 
In the Crito we meet the principle for a third time. Plato's fastidious prose, shunning regurgitation, allows itself repetition of just the one word,

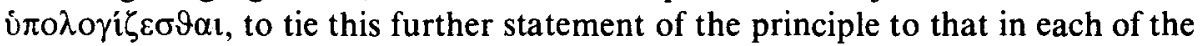
preceding texts:

T12 Cr. 48c6-d5: But for us, since the argument thus compels us (ovi $\tau \omega$ ai $\rho \tilde{i}$ ) the only thing we should consider is ... whether we would be acting justly ... or, in truth, unjustly ... And if it should become evident that this action is unjust

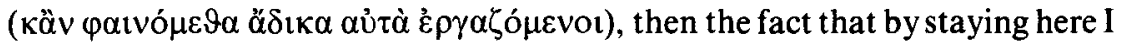
would die or suffer anything else whatever should be given no countervailing

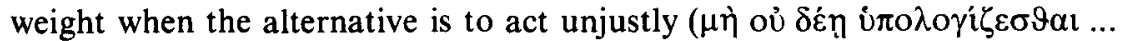

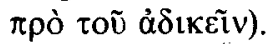

In each of these three texts Socrates is confronting that fatality of our lives which forces us to choose between competing values or, in the more down-to-earth language he uses himself, between competing 'goods' ( $\alpha \gamma \alpha \vartheta \alpha$ ). He would recognize (cf. e.g. Eud. 279a-b) a wide variety of such $\alpha \gamma \alpha \vartheta \alpha$ - physical goods, to begin with: bodily health and strength, good looks; life itself as a biological fact - living as distinct from living well. Next on his list would come those social and intellectual goods which Socrates takes to be morally neutral, seeing no moral merit in their possession or stigma in their dispossession. Such he thinks wealth, social connections, good reputation and prestige, success in politics or war. Such too he thinks that cleverness or quickness of mind which the wickedly cunning may have on a par with the wisely good. ${ }^{40}$ Over against all these he sets the moral goods, his five canonical virtues, all of which, given his well-known doctrine of the unity of the virtues, stand or fall together: whatever stake any of them has in a given choice, each of the other four has the same.

So the principle announced in the above three texts comes to this: Whenever we must choose between exclusive and exhaustive alternatives which we have come to perceive as, respectively, just and unjust or, more generally, as virtuous ( $\kappa \alpha \lambda \alpha$ ) and vicious ( $\alpha \grave{i} \sigma \chi \rho \alpha$ ), that very perception of them should decide our choice. Further deliberation would be useless, for none of the non-moral goods we might hope to gain, taken singly or in combination, could compensate us for the loss of a moral good. Virtue being the sovereign good in our domain of value, its claim upon us is always final.

To take the measure of this commitment we should compare it not with Thrasymachean immoralism or Calliclean antimoralism, nor yet with the skin-deep morality of the homme moyen sensuel, but with that deep regard for virtue we could expect only in the finest characters of the time. Consider Neoptolemus in the Philoctetes. ${ }^{41}$ When first propositioned by Odysseus he recoils with disgust: just to listen to that dishonest proposal, he says, causes him pain, and he 'shudders' at the thought of carrying it out (Phil. 87). ${ }^{42}$ This is his first reaction and, as the drama shows, it will be also his last: he returns the bow, well aware of the sorry 
consequences for himself. And when Odysseus berates the recklessness of that choice, he retorts (1246): 'If it is just, it is better than prudent'. ${ }^{43}$ This is his true character. The bow is in his hands, he need only keep it to be the glorious captor of Troy and who would know, or care, that he had got it by cheating an embittered, paranoiac cripple? Giving it back of his own accord, he proves that he means what he had said at the start: 'I would rather fail acting nobly, than win by acting basely' (94-95). ${ }^{44}$ That sentiment has a Socratic ring. It is what Socrates tells the court after the sentence had been passed: 'I would much rather die, having defended myself as I did, than do as you would have had me do and live' ( $A p .38 \mathrm{e})$. At that point the graph of Socratic morality intersects that of other admirable people in his own world who, like him, vindicate in a crisis the genuineness of their concern for justice by living up to its demands at painful cost to their worldly fortunes. Sophocles was counting on the presence of such people in his audience in those last dismal years of the Peloponnesian war. And so was Isocrates half a century later when he wrote in

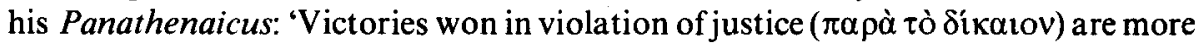
despicable than are morally clean defeats' $(185) .{ }^{45}$

But think how much further the people who would share those fine sentiments would have to go before they could embrace Socrates' principle of the Sovereignty of Virtue. Had Neoptolemus got that far, Sophocles would have lost his play: the stichomythia which starts with Neoptolemus voicing loathing for deceit (100) and ends twenty verses later with abject capitulation ('I'll do it - I'll put up with the shame') could not have occurred: Odysseus would never have had his chance to dangle the prize before the young man's nose. As for Isocrates, it is one thing to hold up to the admiration of his public a rare deed of high resolve, a glittering moral exploit, like the self-immolation of Leonidas and his band, quite another to make the total subordination of comfort, safety, life itself, to virtue the inflexible rule of everyday conduct. The difference becomes palpable in the Gorgias when Socrates argues that to suffer wrong oneself is always better than to wrong another. We know what Isocrates would say to that: 'Forced to choose betwen two options, neither of them ideal, [our fathers] thought it a better choice to do evil to others than to suffer it themselves' (Panath. 117). This, he adds, is what every sensible man would prefer - in fact everybody, except some few 'who pretend to be wise' - as pointed an allusion to Socratic doctrine as can be found in the Isocratean corpus.

Elsewhere $^{46}$ I have argued for the ground-breaking originality of Socrates' interdict on retaliation. Here suffice it to refer to his own awareness of the unbridgeable gulf this interdict creates between his morality and that of all the adherents of the traditional code:

T13 Cr. 49c10-d5: Therefore, we should not return wrong for wrong ( $(\dot{v} \tau \alpha \delta เ \kappa \varepsilon \tilde{i} v)$ nor do evil to a single man, no matter what he may have done to us. And watch out, Crito, lest in agreeing with this you are not going against

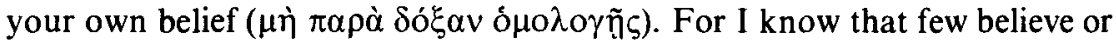


will believe this. And between those who do believe it and those who don't there can be no common counsel: of necessity they must despise each other when they view each others' deliberations.

How Socrates reaches this position is made plain enough in the Crito. That we should never return injustice for injustice is presented as an immediate consequence of the premise that we should never do injustice: from oủ $\alpha \mu \tilde{\omega} \zeta \dot{\alpha} \delta\llcorner\kappa \varepsilon i v$ he derives

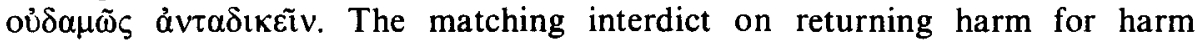

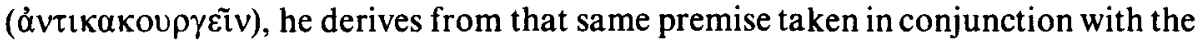
further premise that to do evil to a person is to do injustice to that person. And if we were then to ask, "Why should we grant that first principle - oủ $\alpha \mu \tilde{\omega} \varsigma \grave{\alpha} \delta$ เ $\varepsilon \tilde{i} v$ which is used to derive that twofold renunciation of the lex talionis?' we would get all the answer we need from the principle of the Sovereignty of Virtue. If, when we see that an option is unjust we should reject it instantly without giving any consideration at all to countervailing benefits, then, naturally, we should never do injustice. ${ }^{47}$ And then the question becomes: how does he derive the principle of the Sovereignty of Virtue?

The Apology does not disclose the answer. But the Crito does. What is laid down as an unargued principle in $\mathrm{T} 10$ and $\mathrm{T} 11$ is presented in the Crito as the conclusion of a line of reasoning. Recall how T12 begins: 'But for us, since the argument thus compels us' - thus 'catches us', if we give with Burnet ${ }^{48}$ its literal force to the verb in

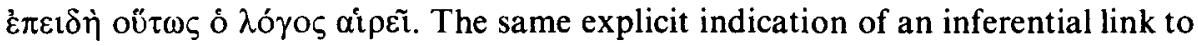
what precedes had been given earlier in the same paragraph, at its start:

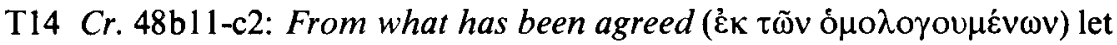

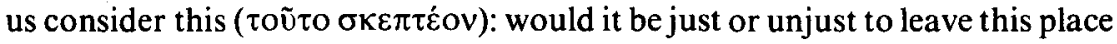
without the consent of the Athenians? If it is just, we shall. If it is not, we shan't...

Here we see a proleptic application of the principle of the Sovereignty of Virtue: the decision between those life-or-death alternatives, to break jail or to stay put to drink hemlock - is to be made solely on the justice or injustice of the matter, shutting out every other consideration. Why so? Because of 'what has been agreed'. And what is that? It is spelled out in the immediately preceding lines:

T15 Cr. 48b4-10: Do we still hold, or do we not, that we should attach highest value not to living, but to living well? - We do. - And that to live well is the

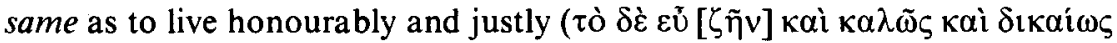

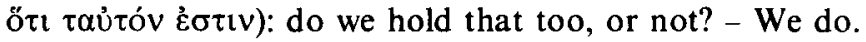

\section{The Identity and Sufficiency Theses}

What should we make of T15?49 Many scholars ${ }^{50}$ have passed it over as a truism. ${ }^{51}$ If we take a closer look at it we will see that it is anything but that ${ }^{52}$ For 
since 'well' is the adverbial form of 'good' and since for Socrates, as for all Greek moralists, the good for man is happiness, ${ }^{53}$ the prima facie meaning of his statement is that the happy and the virtuous form of living are identical, that is to say, that the form of life we call 'happiness' when viewing it under desirability criteria (as the most deeply and durably satisfying kind of life) is the very same form of life we call 'virtue' when viewing it as meeting moral criteria (as the just, brave, temperate, pious, wise way to live). Could any proposition in moral philosophy be less of a commonplace than this? For if this is what Socrates holds it commits him unavoidably54 to the third of the positions laid out above: he is holding that happiness is virtue - virtue its sole component, the only thing that makes life good and satisfying. This is the prima facie import of T15. I shall call it 'the Identity Thesis of the relation of virtue to happiness' or 'the Identity Thesis' for short. But why should I keep saying that this is 'the prima facie' import of the text? Why that qualification? Could there be any doubt on this score? There could indeed. Let me explain.

What we are offered in this text is meant to state the rationale of the principle of

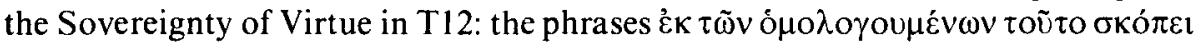
in T14 and $\dot{\varepsilon} \pi \varepsilon 1 \delta \grave{\eta}$ ó $\lambda$ ó course, the Identity Thesis would warrant the implication if we share Socrates' eudaemonist principle, which makes the attainment of happiness the final reason for every rational choice (cf. T24 below). Given this further premise - the tacit premise of the argument - then, certainly, once we are satisfied that of two possible courses of action the one is just, the other unjust, the identity of virtue and happiness would immediately decide the choice: the unjust course would not deserve even a second look if it is known to be the unhappy one. So for a eudaemonist the Identity Thesis would indeed meet the requirement of compelling acceptance of the principle of the Sovereignty of Virtue. But it over-satisfies that requirement. The principle does not require so strong a premise: the thesis 'catches' the principle, but the principle does not 'catch' the thesis. It doesn't, because the scope of the principle is so much narrower than that of the thesis. The principle only tells us how we should choose when the alternatives are virtuous and vicious respectively. It does not tell us how we should choose when the alternatives are not of that sort at all - when both options are acceptable from the moral point of view. Yet choices of this latter sort may make a real - at times a drastic-difference to our happiness, while on the Identity Thesis they should make none: if virtue is identical with happiness, then options equally consistent with our virtue should be equally consistent with our happiness. But in point of fact they are not.

To illustrate: imagine that in the strange house where I must spend the night alone I have the choice of two beds. One is freshly made and the sheets are clean. The other was slept in the night before by someone in a drunken stupor who vomited on the bed: the sheets are still soggy from the remains. Since my virtue would be unimpaired if, clenching my teeth and holding my nose, I were to crawl in 
between those filthy sheets for a bad night's sleep, why should my happiness? I trust the grossness of the example will not offend: misplaced delicacy is an impediment to clear thinking on moral topics, as Socrates would be the first to observe. I trust also that the example will not be brushed aside on the ground that it concerns the happiness of a few hours, while the happiness Socrates is talking about is a longrun, ideally, a life-long business: I could easily concoct examples to fit that bill, say, life in a concentration camp. If happiness were identical with virtue, an inmate of Gulag should be as happy as an equally virtuous inmate of a Cambridge College. Or, to use a Biblical fable, if happiness were identical with virtue, Job should be as happy after Satan's work has been done as he was before - the loss of his seven thousand sheep and five thousand camels and of all his kin, the running sores that cover him from head to foot, should not result in the slightest diminution of his happiness.

Is there then no alternative to the Identity Thesis which would provide a rational ground for preference between courses of action indistinguishable in respect of virtue but differing materially in other ways? There surely is. Let me sketch a possible model of it. Keeping virtue in its place as the sovereign good, both necessary and sufficient for happiness, let us allow happiness a multitude of lesser constituents in addition to virtue. Everything on Socrates' list of non-moral goods (cf. p. 187 above) would come in under this head. In isolation from virtue each would be worthless. ${ }^{55}$ But when conjoined with virtue (i.e. when used virtuously) they would enhance happiness in some small degree. ${ }^{56}$ Variations in happiness which, on the Identity Thesis, would be a function of a single variable, on this alternative model would be a function of many variables: all of those non-moral mini-components of happiness would be decremental or incremental in some small way: each would make a mini-difference, greater in the case of some than of others; thus the enhancement of Job's happiness would be greater if he regained his health than if he got back his camels. ${ }^{57}$

Here we see the possibility of two alternative theories of the relation of virtue to happiness, premised on different conceptions of happiness. A unicomponent model of happiness would yield the Identity Thesis. The multicomponent model I have just sketched would yield, alternatively, what I shall call the Sufficiency Thesis, ${ }^{58}$ since on this model virtue, remaining the invariant and sovereign good, would of itself assure a sufficiency of happiness - enough of it to yield deep and durable contentment - but would still allow for small, but not negligible, enhancements of happiness as a result of the virtuous possession and use of non-moral goods. I want to argue that, appearances to the contrary notwithstanding, the Sufficiency, not the Identity, Thesis gives the right insight into the Socratic view. Let me probe those appearances. What do the texts really say?

Doesn't T15 say that the happy and the virtuous life are identical? It says that

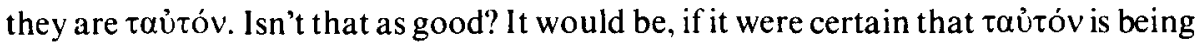
used here to express identity. Could there be any question as to that? There could 
indeed. Aristotle, the first Greek thinker to investigate that innocent-looking term, ${ }^{59}$ concludes that when two general terms, $A$ and $B$, are said to be $\tau \alpha \dot{\tau} \tau o$ v any one of three different things could be meant. These are his first two: ${ }^{60}$

(i) that $A$ and $B$ are synonyms or that they 'are the same in definition';

(ii) that $B$ is, in technical Aristotelian terminology, a 'proprium' (i $\delta ı v)$ of $A$, i.e. that while $B$ is not the 'essence' of $A$, the two are nonetheless necessarily interentailing. ${ }^{61}$

The first, which Aristotle takes to be the 'primary and principal' use of the term, will not fit our text at all: 'happiness' and 'virtue' are certainly not meant to be synonyms, nor are they supposed to have the same definition. What about the second? It clearly fits on the Identity Thesis, where 'happiness' and 'virtue' are the same form of living differently described. But it also does on the Sufficiency Thesis: When $A$ and $B$ are necessarily interentailing, then, necessarily, $x$ has attribute $A$ if, and only if, $x$ has attribute $B$, and then $x$ may (but need not) have certain additional attributes, say, $C$ and $D$, necessarily interentailing with attributes $E$ and $F$, respectively. On the Sufficiency Thesis $A$ would stand for virtue, $B$ for the form of happiness which is found necessarily and exclusively in virtue; $C$ and $D$ might stand for, say, health and wealth, ${ }^{62}$ and $E$ and $F$ for the increments of happiness associated with health and wealth, respectively, when these are virtuously used. On these terms 'happy' and 'virtuous' would be interentailing and would, therefore, qualify for being 'the same' in sense (ii), though the degrees of happiness experienced by virtuous persons differently circumstanced with respect to nonmoral goods would differ. ${ }^{63}$ Thus the Sufficiency Thesis would fit T15 no less than would the Identity Thesis. ${ }^{64}$

We may now investigate three texts which, like T15, appear to give the very strongest possible support to the Identity Thesis but, as I shall argue, turn out on closer scrutiny to be equally consistent with the rival thesis. I start with the one which I take to give the clue to the right reading of all three:

T16 Ap. 30c5-d5: (a) You should know well that if you kill the sort of man I say $\mathrm{I}$ am you will harm yourselves more than me. Me neither Meletus nor Anytus could harm: they could not, for it is not permitted that a better man be harmed by someone worse than himself.

(b) He could kill me, perhaps, drive me into exile, deprive me of civic rights. He and others might think that these are great evils. But I don't. Much greater is the evil he is attempting now - to send a man unjustly to death. ${ }^{65}$

Does Socrates really mean that Meletus and Anytus 'could not' harm him, knowing well that they could bring about his death, exile, $\alpha \tau \iota \mu$ í $\alpha$ ? If he did he would be 
asserting that these - and, by the same token, any other -- non-moral evils would make zero difference to his happiness. But look at what he goes on to say in part (b) of our text: not that they can do him no evil, but that they can do him no great evil. Is he dithering, thinking those calamities non-evils at (a), mini-evils at (b)? There is no need to suppose that there is any vacillation at all; he can be reasonably understood to be making the same point in both parts of the text. To see this we must take account of that special use of negation, available in all natural languages, Greek no less than English, whose purpose is not to deny the applicability of the predicate, but to de-intensify its application. You ask, 'Might I trouble you to post this letter for me'? and I reply, 'It would be no trouble - none at all', though I know and you know that the errand would take me several blocks out of my way. You understand me to say 'no trouble' and mean 'a mini-trouble - too trivial to be worth mentioning'. If we were entitled to read such a use of negation in T16(a), what is said there would fit the Sufficiency Thesis fully as well as does what is said in T16(b).

Are we then entitled to so read T16(a)? There is reason to think so. Consider what Socrates had been saying a few lines earlier in the Apology:

T17 Ap. 30a8-b4: (a) [1 ask you] to make your first and strongest concern not wealth but the soul - that it should be as virtuous as possible.

(b) For virtue does not come from wealth, but through virtue, wealth and everything else, private and public,

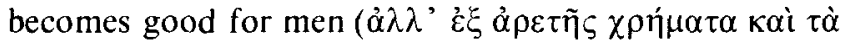

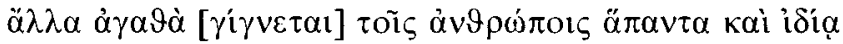
кai $\delta \eta \mu \sigma \sigma i \alpha){ }^{66}$

In (a) he is reiterating the sentiment he had voiced just before:

T18 Ap. 29e5-30a2: ... if he appears to me not to have the virtue he says he has, 1 shall reproach him for setting least value on the things of the greatest value and setting the greater on inferior ( $\varphi \alpha \cup \lambda \delta$ ó $\tau \varepsilon \rho \alpha)$ things.

What Socrates is saying here fits perfectly the framework of the Sufficiency Thesis. $\mathrm{He}$ is not saying that the non-moral goods he has been talking about (money, reputation, prestige) have no value at all, but that their value is vastly inferior to that of the most precious thing in life: perfection of soul. In T17(b) he explains why the latter should hold so preeminent a place in our scheme of value: this is what makes all other things good; ${ }^{67}$ without this nothing else would be good. Since there is no reason to think that this perspective on non-moral goods has altered, less than a page later, in T16, we are justified in reading the message in T16(a) in the same way, hence as the same message as in T16(b). Should there still be hesitation on this point, here is a further consideration to allay the doubt: In that special use of "no trouble' in my example, negation functions as an implicit comparative: the phrase is, in effect, a contraction for 'no trouble bl' comparison with the vastly greater 
trouble I would gladly take to give you pleasure'. ${ }^{6}$ Apply this to the remark in T16(a) that Meletus and Anytus 'could not harm him': What he is trying to get across in both parts of T16 is the triviality of what his prosecutors could do to him by comparison with the enormity of what they are doing to themselves. In (b) this thought is fully explicit ('much greater is the evil he is attempting now'); it follows the denial that what Meletus could do to Socrates would be 'the great evils' they are thought to be and explains how that denial should be understood. In (a) the same comparison ('you will harm yourselves more than me') introduces the denial that Meletus or Anytus could harm him and similarly shows how it is to be understood. The point of saying in (a) that he could not be harmed is the same as that of saying in (b) that he could not be greatly harmed: both are instruments of the same comparison, ${ }^{6 y}$ alternative ways of expressing the same thought.

We may now look at two more texts which, if taken at face-value, would be conclusive evidence for the Identity Thesis:

T19 Ap. 41c8-d2: But you too, my judges, must be of good hope towards death and bear this truth in mind: no evil can happen to a good man either in life or in death...

T20 Rep. 1. 335cl-7: And shall we say the same about men, that when they are harmed they are made worse in respect of human excellence? - Certainly. - And is not justice human excellence? - Absolutely. - Hence, necessarily, when men are harmed they are made more unjust.

In T19 he says 'no evil' can happen to him. In T20 the conclusion - that when men are not harmed they are necessarily made more unjust, entails, by modus tollens, that when they are not made more unjust they are not harmed. Can Socrates say this, knowing quite well that men may be robbed, imprisoned, tortured, blinded, without being made more unjust? He obviously can on the Identity Thesis. But so too on the Sufficiency Thesis if we carry forward into our reading of each of these new texts what we learned in T16(a) via T17 and T18 and the de-intensifying use of predicate negation. If in T16(a) Socrates could use 'no evil' as a simple variant for "no great evil' in T16(b), then what he says in T19 and T20 each of them to all appearance hard evidence for the Identity Thesis, can be similarly read as consistent with its rival.

There is still another text where, as in T16 above, the initial impression of unambiguous support for the Identity Thesis dissipates when the text is read as a whole:

T21 Grg. 470e4-11: Obviously then you'd say you don't know if even the Great King is happy. - And that would be the truth, for I don't know how he stands in culture and justice. - What? Does all of happiness depend on that ${ }^{71}$

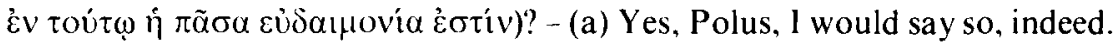
(b) For I say that the honourable and good man and woman is happy, the 
unjust and wicked is miserable.

If what Socrates says in (a) were literally meant - that all of happiness depends on 'culture and justice' - he would be ruling out the eudaemonic value of everything but virtue; he would be saying that virtue is the only good. ${ }^{71}$ The foregoing argument for deflating the quantifier in T16(a) - for taking 'no harm' to mean 'no great harm' - prompts the question whether the same semantic operation might not be in order also here. ${ }^{72}$ The question admits of a firm 'Yes' once we note two things about the follow-up to (a) in (b): first, that (b) purports to give the reason ( $\gamma \alpha \dot{\alpha} \rho$ ) for what is asserted in (a), thereby implicitly explaining what is meant at (a); secondly, that the relation of virtue to happiness which is expressed in (b) is, unmistakeably, interentailment, not identity: Socrates does not say that happiness is that very thing ( has virtue. And if we want reassurance that precisely this constitutes his mature, fully considered view, it is supplied us in full measure later on in the dialogue, when Socrates sums up as follows the upshot of his long argument against Callicles:

T22 Grg. 507b8-c7: So there is every necessity, Callicles, (i) that the temperate man who, as we have seen, will be just and brave and pious, will be a perfectly good man, and the good man will act well and nobly in whatever he does, and he who acts well will be blessed and happy; and (ii) that he who is wicked and acts badly will be miserable...

Simplifying this more elaborate statement, trimming it down to just those assertions which are essential for my present argument, what is said here comes to this:

(i) if one were perfectly virtuous then, necessarily, one would be happy, i.e. that virtue necessarily entails happiness, and moreover

(ii) if one were vicious then, necessarily, one would be miserable, i.e. that vice entails unhappiness and thus (by modus tollens) that happiness necessarily' entails virtue.

Putting (i) and (ii) together, we get

(iii) virtue and happiness are necessarily interentailing.

This is what Socrates feels he has established in the pièce de résistance of the whole dialogue. Thus interentailment is indubitably the relation of virtue to happiness in $\mathrm{T} 21(\mathrm{~b})$ and $\mathrm{T} 22$, therefore also in $\mathrm{T} 21$ (a), confirming the previous argument that just this was the relation expressed via tautóv in T15. So the relation of virtue to happiness asserted in all three of these texts is equally consistent with the Identity and with the Sufficiency theses.

What should we conclude from this review? Suppose we could have put our question to him: 'Tell us, Socrates, which of those two theses we blocked out for you 
represents your view? What does your picture of happiness look like: is it a monochrome, all of the space for happiness filled by a solid colour, say, blue, standing for virtue? Or is the picture a polychrome, most of it painted blue, but flecked out with a multitude of other colours, each of those specks making some tiny but appreciable contribution to the design?' We scan several dicta of his, trying to read from them his answer, and we are disappointed by their failure to speak out loud and clear. Several of them - T15, T16(a), T19, T20, T21(a) - at first look like flat endorsements of the Identity Thesis. ${ }^{74}$ But when scrutinized more closely all of them are seen to be consistent with the Sufficiency Thesis too, as is the case from the start in T16(b), T21(b), T22, while two of them, T17 and T18, are more than just consistent with the Sufficiency Thesis: they speak from its own point of view, that of the incomparably higher value of virtue, not of its exclusive value. So the evidence so far considered, taken as a whole, cannot be said to favour the Identity Thesis to the exclusion of the Sufficiency Thesis. But I do not wish to stop with that. I want to argue that Socrates has a compelling reason to opt for the Sufficiency Thesis, and shall produce textual evidence that he is in fact committed to it.

\section{For the Sufficiency Thesis}

I may put that reason bluntly: If Socrates had opted for the Identity Thesis he would have made a perfectly senseless decision. I do not mean to echo Aristotle's sally against those thinkers who, he thought, were crediting the virtuous man's happiness with impossible invulnerability to misfortune: 75

T23 Arist. E.N. 1153b 19-21: Those who say that a man who is being tortured and has suffered terrible calamities is happy if he is a good man are willy-nilly talking nonsense.

Why nonsense? If Aristotle were charging conceptual error - which I do not think he is - I would disagree. If Socrates believes that human beings could remain happy in the most extreme suffering, I would marvel at his faith in the sublime capacities of human nature, but $I$ would see no contradiction in it, no logical reason why it could not be true. It is not for this that I would fault the Identity Thesis. After all, on this point it is no different than its rival. In either case Socrates would be making heroic demands on human nature. But the Identity Thesis does something more. It requires that all those values which are strictly non-moral on Socrates' reckoning should make zero difference to happiness.

Consider the consequence, given his view that

T24 Grg. 499e 7-8: The good [= happiness] $]^{76}$ is the final end ( $\tau \dot{\varepsilon} \lambda \circ \varsigma$ ) of all our actions; everything must be done for its sake,

i.e. that happiness is the final reason which can be given for any purposeful action, hence for any rational choice between alternative courses of action. It follows that if 
the Identity Thesis were true, we would have no rational ground for preference between alternatives which are equally consistent with virtue - hence no rational ground for preference between states of affairs differentiated only by their nonmoral values. And if this were true, it would knock out the bottom from eudaemonism as a theory of rational choice. For most of the choices we have to make throughout our life have to be made between just such states of affairs, where moral considerations are not in the picture at all: Shall I walk to my destination or ride the bus? Shall I have my hair cut today or next week? Shall I have Burgundy or Rosé for dinner, or no wine at all? We do make such choices all the time, and we want to make them: we would resent it fiercely if they were taken out of our hands. And the grounds on which we have to make them are clearly non-moral: hedonic, economic, hygienic, aesthetic, sentimental, or whatever. This being the case, if the Identity Thesis were true it would bankrupt the power of eudaemonism to give a rational explanation of all our deliberate actions by citing happiness as our final reason for them. On that theory, if happiness were identical with virtue, our final reason for choosing anything at all would have to be concern for our virtue; so the multitude of choices that have nothing to do with that concern would be left unexplained. ${ }^{77}$ To avoid this consequence all Socrates would have had to do is opt for the Sufficiency Thesis, whose mini-goods fill exactly the gap in the explanatory scope of the eudaemonist theory if the Identity Thesis were true. Were Socrates to deny himself this option he would be making an utterly gratuitous choice - a totally unnecessary one, since the Sufficiency Thesis would serve as well the moral purpose of his theory of the relation of virtue to happiness. ${ }^{78}$

Can we say more - not only that this would have been the right decision for Socrates to make, but that he gives positive evidence of being committed to it? We can.

T25 Grg. 467el-468b4: Now is there anything in existence that isn't either good or bad or intermediate between the two: neither good nor bad? ... And you call 'goods' ${ }^{79}$ wisdom and health and wealth and other things of that sort? ... And by 'neither good nor evil' don't you mean things of this sort: which partake now of the one now of the other and at times of neither - for example, sitting and walking and running and sailing; and again stones and sticks and other things of that sort? ... And when people do those intermediate actions, do they do them for the sake of the good things, or the good things for the sake of the intermediates? ... So it is in pursuit of the good that we walk when we walk, thinking this would be better, and when, on the contrary, we stand, this too we do for the sake of the good? Or not?...

Here 'everything in existence' is trichotomized into things (objects or actions) which are either [a] good or [b] evil or [c] neither good nor evil ('intermediate' between good and evil, hence 'intermediate' for short). Into box [c] he puts everything which can have only instrumental value - physical objects, like sticks and stones, and 
physical actions, like sitting or standing, which, it is assumed, we would never perform for their own sake, but only for the sake of some end external to themselves. ${ }^{80}$ Into box [a] he puts all 'goods' - all those things for whose sake we may want any 'intermediate' whatever. As examples he gives a moral good, wisdom, and two non-moral goods, health and wealth. This would be unintelligible if he were accepting the Identity Thesis, which identifies the good with virtue and assigns purely instrumental status to non-moral goods: if Socrates were tacitly opting for the Identity Thesis he would not dream of putting health and wealth into box [a]. Conversely, this move is exactly what it should be on the Sufficiency Thesis which assigns intrinsic, value to non-moral goods, accepting them as components of the good, without thereby elevating them to preference parity with the moral goods: nothing of this sort is suggested in T25 nor anywhere else in the Gorgias; the absolute subordination of all other goods to virtue is maintained as strongly in this dialogue as anywhere in the Platonic corpus. ${ }^{81}$

Further evidence for the Sufficiency Thesis is available in the Gorgias:

T26 Grg. 469b 12-c2: Would you then wish to suffer injustice rather than do it? - For my part I would wish neither. But if I were forced to choose between suffering injustice and doing it, I would choose to suffer it.

Confronting two states differentiated only by their non-moral value - in the one he does suffer injustice, in the other he doesn't - Socrates says flatly that he would not wish the former. Why so, if suffering injustice would not affect his virtue in the slightest? If his sentiments were in conformity with the Identity Thesis, he would be saying that neither would it affect his happiness in the slightest - so why should he care whether or not he suffers injustice? Since he does care - he is not a moral masochist, he objects to being victimized by predators - he must be tacitly endorsing the Sufficiency Thesis: only this thesis would justify a preference for courses of action morally on a par with alternatives to which they are superior only on non-moral grounds - because they would spare him the loss of property or reputation or health or life or any of those other non-moral goods which would be filched from him if he suffered injustice.

We get more to the same effect in the discussion of pleasure in the Gorgias:

T27 Grg. 499c7-500a3: Some pleasures are good and some bad. Is it not so? ... And the good ones are the beneficial, the bad ones the harmful? ... Now is this what you mean: Of the bodily pleasures - of eating and drinking, for instance - are not the good ones those that produce bodily health or strength or some other bodily excellence, the bad ones those which do the opposite?... Then pleasant actions, as well as (all) others, should be done for the sake of the good, not the good for the sake of pleasure?

To decide between different options on the menu - highly seasoned gourmet dishes or plainer fare, optimally healthful - Socrates does not instruct us to use moral 
criteria. Taking it for granted that these will be satisfied to begin with (nothing could count as good pleasure for Socrates if it involved sacrifice of moral values), he refers simply to the effect of either option on our physique. We are to decide by considering which option will 'produce health or strength or some other bodily excellence'. ${ }^{82}$ Pleasure secured in default of this will be a bad pleasure, we must forgo it 'for the sake of the good', the relevant part of the good being in this case explicitly non-moral. So here again, as explicitly in T23 and implicitly in T25, he is counting non-moral values as bona fide constituents of happiness - miniconstituents, to be sure, not worth a second look if they would tempt us away from the path of virtue but, even so, once the demands of virtue have been satisfied, sound guides to right choice between alternatives.

This position is maintained in the protreptic discourse in the Euthydemus (278e282d) and in its miniaturized doublet in the Meno (87e-88e) where the Socratic thesis that virtue 'is' knowledge is defended. ${ }^{83}$ I quote the lines in which the discourse in the Euthydemus comes to a head:

T28 Eud. 281d2-el:(a) In sum, I said, it would appear, Cleinias, that in the case of all those things which we first said were good, ${ }^{84}$ our view is that it is not their nature to be good just by themselves ${ }^{85}$ (ö $\pi \omega \zeta \alpha u \dot{\tau} \alpha^{\prime} \gamma \varepsilon \kappa \alpha \vartheta^{\prime} \alpha \dot{\alpha} \tau \grave{\alpha} \pi \dot{\varepsilon} \varphi v \kappa \varepsilon v \dot{\alpha} \gamma \alpha \vartheta \grave{\alpha}$ [Elval]). But this is the truth of the matter, it seems: if ignorance controls them they are greater evils $(\mu \varepsilon i \zeta \omega$ $\kappa \alpha \kappa \alpha$ ) than their contraries to the extent of their greater power to serve their evil leader; while if they are controlled by sound judgment ( $\left.\varphi \rho \operatorname{vo}_{\eta} \sigma \mathrm{\iota} \zeta\right)$ and wisdom $(\sigma \circ \varphi i \alpha)$ they are greater goods $(\mu \varepsilon i \zeta \omega \hat{\alpha} \gamma \alpha \vartheta \dot{\alpha})$, though both are worthless just by themselves ( $\alpha \dot{v} \tau \alpha \dot{\delta} \delta \dot{\varepsilon} \kappa \alpha \vartheta^{\prime} \alpha \dot{u} \tau \dot{\alpha}$

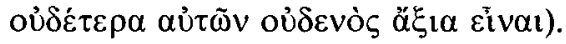

(b) What follows from what has been said? Is it anything but this: that none of those other things is either good or evil [just by itself], while there are two things of which one - wisdom - is good [just by itself], the other ignorance - is evil [just by itself]?

That non-moral goods of whatever description are good only in conjunction with virtue ('wisdom'86) is the position we have seen Socrates hold all along: explicitly in the Apology (T17(b): 'virtue is what makes 'wealth and all other things good for men'), implicitly in the Gorgias (T21(b), T22: virtue is a necessary condition of happiness, hence of the eudaemonic value of everything else). In T28(a) this thought is pushed one step further: wealth, health, etc., good though they are when used virtuously, would be positively bad, 'greater evils than their contraries,' if they were viciously used. 
So far things are plain enough. But in part (b) of our text there is trouble - or, rather, there would be, if we were to take at face value the phrase I have italicized in the citation. For if we did, we would have to understand Socrates to be saying that health, wealth, etc. are neither good nor evil which, it will be recalled, was the description in T25 above of the third division in the trichotomy he had laid out there: things which are [a] good, [b] evil, [c] neither good nor evil. This scheme had established the categorial difference between constituents of the good in [a], which included both moral and non-moral goods (both 'wisdom' and 'health and wealth'), and the things in [c] which have no intrinsic value, are never desirable for their own sake, but only for the sake of some good. Socrates had kept faith with this categorial scheme throughout the Gorgias: his adherence to it shows up later in the dialogue, in T27. In dialogues which follow the Gorgias the non-moral goods continue to be placed in division [a]: in the Lysis (218e) Socrates asks about health, 'Is it good or evil or neither?' (the same trichotomy as in T25) and answers firmly, as before, 'It is good'; in the Meno (78c), he asks, "And by "good" don't you mean such things as health and wealth?, leaving no doubt as to the answer. The same thing happens in the Euthydemus prior to T28 and independently of it: health and wealth appear again as straightforward examples of 'goods' (279a-b) no less than are the moral goods $(279 b-c) .{ }^{87}$ Thus if Socrates were to assert in T28(b) that health, wealth, etc. are neither good nor evil, thereby transferring them from [a] to [c] in the trichotomy, ${ }^{88}$ he would be deserting a categorial scheme he had maintained in all the dialogues which speak to the issue from the Gorgias to the Meno, including the Euthydemus prior to T28. The inconsistency would be palpable. Is there no way of reading that italicized phrase in $\mathrm{T} 28(\mathrm{~b})$ which would preserve consistency?

There surely is, and the best clue to it is in the very words in which T28(b) leads off: 'What follows from what has been said?' Well, what does follow from the truth expounded in T28(a), namely that the possession of non-moral goods will enhance our happiness if, and only if, we possess the wisdom to guide our use of them aright? What does follow, surely, is precisely what I have indicated in my citation of the text by the interpolated expansions: namely, that no non-moral good is good just by

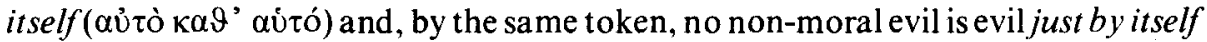
(since it is their conjunction with wisdom or with ignorance that will decide if either non-moral goods or non-moral evils will enhance or impair their possessor's happiness), while the moral good, wisdom, is good just by itself and, by the same token, the moral evil, ignorance, is evil just by itself (since in their case their enhancement of their possessor's happiness or unhappiness does not depend on anything else). ${ }^{89}$ Thus if we read the expression 'either good or evil' as a contraction for 'either good [just by itself] or evil [just by itself]' perfect sense will result, its entailment by what was said in T28(a) will be assured, ${ }^{90}$ and no violence to the categorial scheme established in the Gorgias will be done: health, wealth, etc. will hold their place in division [a] of the trichotomy at T25 as constituents of happiness, but their hold on it will be conditional or contingent: ${ }^{91}$ each will be a constituent of 
their possessor's happiness if, and only if, he or she has wisdom. ${ }^{92}$

Collecting the results obtained in the present section and splicing into them what may be learned from another major passage, the account of the proton philon in the L.'sis $(219 \mathrm{~b}-220 \mathrm{~b})$, we get the following scheme of value:

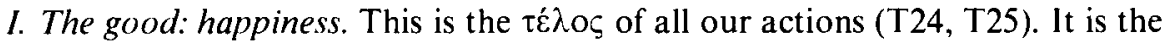
prōton philon for whose sake all other dear things are dear, "while it is not itself dear for the sake of any other dear thing' (L1.220bl-5), for the sequence ' $x$ is desired for the sake of $y, y$ for the sake of $z, \ldots$ cannot be unending. ${ }^{93}$

II. The invariant, necessary, and sovereign constituent of the good: moral virtue. ${ }^{94}$ This should be the $\sigma \kappa 0 \pi$ ó $\zeta$ by which all our actions are guided ( $G r g .507 \mathrm{~d} 6-$ el), for regardless of what other goods we may gain or forfeit, only if we achieve this constituent of the good can we be happy (T21), blessed and happy (T22). ${ }^{95}$

III. The variable, contingent, and subordinate constituents of the good: nonmoral goods. ${ }^{96}$ The difference to our happiness these can make is minuscule. But goods they are (T25, T27, Ly. 218e, Eud. 279a-b, Meno $78 \mathrm{c}$ and $87 \mathrm{e}$ ); we shall be happier with than without them, but only if we use them aright, for they are not 'good just by themselves': if separated from wisdom they will go sour on us and we shall be worse off with them than we would be without them (T28, Meno 87e-88d).

$I V$. The 'intermediates': things which have no intrinsic value (T25). ${ }^{97}$ They are reckoned neither good nor evil because they are not constituents of the good, are never desired for their own sake, but only for the sake of goods. ${ }^{98}$

\section{Conclusion}

In Section IV above we start with texts whose prima facie import speaks so strongly for the Identity Thesis that any interpretation which stops short of it looks like a shabby, timorous, thesis-saving move. What else could Socrates mean when he declares with such conviction that 'no evil' can come to a good man (T19), that his prosecutors 'could not harm' him (T16(a)), that if a man has not been made more unjust he has not been harmed (T20), that 'all of happiness is in culture and justice' (T16)), that living well is 'the same' as living justly (T15)? But then doubts begin to creep in. Recalling that inflation of the quantifier is normal and innocuous in common speech ('that job means everything to him, he'll do anything to get it, will stick at nothing') we ask if there is really no chance at all that 'no evil' in T19, 'not harmed' in T20 might be meant in the same way? The shift from 'no harm' at T16(a) to 'no great harm' at T16(b), once noticed, strengthens the doubt. It gets further impetus in T21(b) when to explain how 'all of happiness is in culture and justice' he depicts a relation (that recurs more elaborately in T22) which, though still enormously strong, is not quite as strong as would be required by identity. The doubt seeps into T15 when we note that current usage did allow just that relation as a respectable use of 'the same'.

At that point we begin to wonder if resort to the Identity Thesis might not be just 
a first approximation to a subtler, more finely nuanced, doctrine which would give Socrates as sound a foundation for what we know he wants to maintain at all costs the Sovereignty of Virtue - without obliterating the eudaemonic value of everything else in his world. We cast about for a credible model of such a relation of virtue to happiness and hit on that multicomponent pattern sketched on p. 191 above. We ascertain that this will afford a comprehensively coherent eudaemonist theory of rational action, while its rival would not, and will fit perfectly a flock of texts in Section V which the latter will not fit at all. Are we not entitled to conclude that this is our best guide to the true relation of virtue to happiness in Socrates' thought - the one for which he would have declared if he had formulated explicitly those two alternative theses and made a reasoned choice between them? ${ }^{99}$

DEPARTMENT OF PHILOSOPHY

UNIVERSITY OF CALIFORNIA AT BERKELEY

GREGORY VLASTOS

NOTES

1. The "Socrates" of this paper is the protagonist of Plato's earlier dialogues. I list these (by selfexplanatory abbreviations, borrowed from T. Irwin, Plato's Moral Theory [1974] hereafter 'PMT): Ap., Ch., Cr., Eud., Eu., G., HMa, HMi, Ion, La., Ly., Pr., R. I. I assume, but shall not argue here, that in this segment of his corpus, Plato aims to recreate the doctrines and arguments of his teacher in dramatic scenes, all of which (except for the $A p$.) may be, and most of which undoubtedly are, fictional; I shall be referring to them, under this proviso, as Plato's 'Socratic dialogues.' (I did not include the Menexenus in the above list, since the parody of a funeral oration in this dialogue is explicitly dissociated from Socrates.)

2. Pr. 319aff.; M. 70aff., $79 \mathrm{cff}$.

3. That he takes his list to be complete is a reasonable inference from the fact that whenever the 'parts' of virtue are enumerated (cf. nn. 4 and 5 below) or when what it takes to be a 'perfectly good man' is spelled

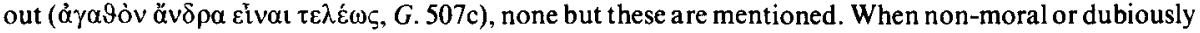

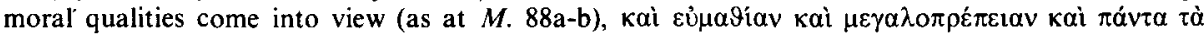
$\tau o t \alpha \tilde{\tau} \tau)$ they are not called $\alpha \rho \varepsilon \tau \alpha i$, but brought, along with the moral virtues, under the more general

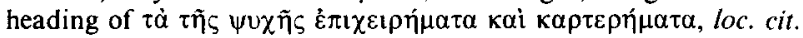

4. Pr. 329cff., 349cff., 359aff.; La. 199e; M. 79a-d.

5. La. 190c; M. 89a.

6. This narrowly moral construction of $\alpha \rho \varepsilon \tau \eta \dot{~ i s ~ c h a r a c t e r i s t i c a l l y ~ S o c r a t i c . ~ A r i s t o t l e ' s ~ u s a g e, ~ w h i c h ~}$

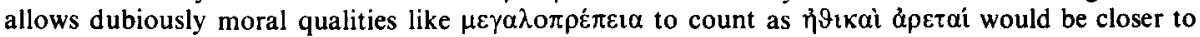

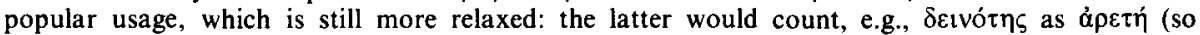

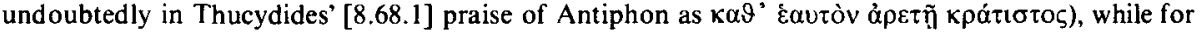

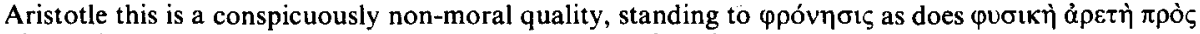

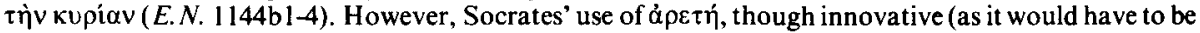
to implement his profoundly new conception of moral excellence), is not eccentric. It retains good contact with popular usage whose vagaries even allow upon occasion startling anticipations of Socrates (as in Theognis 147-47, 


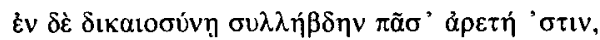

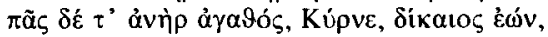

on which, however, see K. J. Dover, 'The portrayal of moral evaluation in Greek poetry', JHS(1983) 3548 at 48 ) and, in any case, frequent use of ảpetr more Socratico in stark contrast to conduct dominated by considerations of pleasure or profit, as in Thucydides' description of the Spartans [5.105.4]: at home

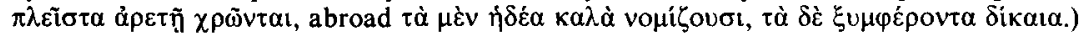

7. W. D. Ross, Aristotle 1 (1923) 190. So too, earlier, H. Sidgwick, Methods of ethics 7 (1907) 92.

8. John Ackrill, Aristotle the philosopher (1980) 14.

9. W. D. Ross in J. A. Smith and W. D. Ross (eds), The works of Aristotle translated into English (191052). John Ackrill, Aristotle's ethics (1973).

10. The ineptness of 'well-being' for $\varepsilon \dot{\delta} \delta \alpha \mu$ ovi $\alpha$ in contexts of this sort speaks for itself. So should that of 'human flourishing' (defended, John Cooper, Aristotle on human good (1975) 89 n. 1; rejected, R. Kraut, 'Two conceptions of happiness', Philos. Review (1979) 167-97, at 168-170.) For a vigorous defense of the traditional translation see also James Dybikowski, 'Is Aristotelian Eudaimonia Happiness?' Dialogue (1981) 185-200.

11. E.N. 1178 b9-10 and 20-23.

12. Ross (n. 7 above) 190.

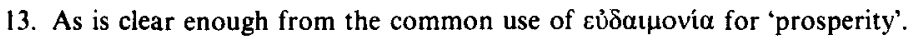

14. 'Happiness' here is strictly self-referential: it stands for the agent's happiness and that of no one else. This is so deep-seated an assumption that it is simply taken for granted: no argument is ever given for it in the Platonic corpus. (For this assumption in the context of T6 cf. the gloss on $S m p$. 206a and 207a in my Platonic Studies 2 (1981) 20 n. 56 sub fin. For the same assumption in Socratic dialogues see e.g. how

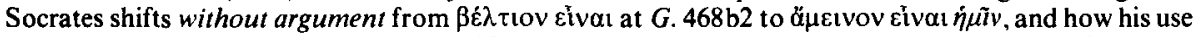

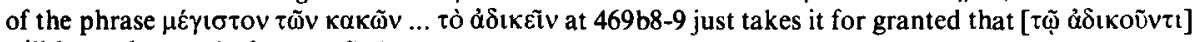
will be understood after $\kappa \alpha \kappa \tilde{\omega} v$.)

15. Cf. T24 below.

16. Hume's explanation of the notion of 'ultimate ends' of conduct is exactly the same (though the plural, to which I have called attention, constitutes a fundamental residual difference): Enquiry concerning the principles of morals, Appendix I, Section V ('It is impossible there can be a progress in infinitum; and that one thing can always be a reason why another is desired. Something must be desired on its own account...').

17. So H. A. Prichard argued in his famous essay, 'Does moral philosophy rest on a mistake?' (Moral Obligation (1949), the first essay, first published in 1912).

18. Pace Xenophon's hostile portrayal of him (Memorabilia 2.1 and 3.8), this 'sophist' (Aristotle, Metaph. 996a32) was undoubtedly a member of Socrates' inner circle: cf. Plato, Phaedo 59c2-3, and Aristotle, Rhet. 1399a7-9.

19. Throughout this paper I shall be using these terms interchangeably. They are so used by Socrates and, after him, by all Greek moralists in antiquity. For his own usage see e.g. how freely he interchanges the terms in his statement of the Calliclean thesis at $G .494 \mathrm{e}-495 \mathrm{~b}$ : "those who have pleasure, pleasure of whatever sort, are happy' or again, without any intervening explanation, 'this is the good - to have pleasure of whatever sort.' 
20. Not that it must: nothing is said in the $G$. to commit the hedonist to a Calliclean strategy of pleasuremaximization (whose imprudence is clearly indicated [488d-489b; cf. $R .1,35$ la-352d]). Had Socrates thought that hedonism entails antimoralism, his association with Aristippus would be unintelligible.

21. More than a third of the texts on which I base my account of the Socratic view below are from the $G$., and these are so informative that at a pinch the whole account could have been worked up just from them: all four of the categories in the Socratic scheme of value which sums up the findings in Sections IV and $\mathrm{V}$ could be documented from the $G$. alone.

22. Including the Pr., for I believe that rigorous analysis of Plato's text (for which see Donald Zeyl, 'Socrates and Hedonism - Pr. 35l b-358d', Phronesis (1980) 250-69) shows that Socrates never asserts in propria persona the hedonistic premise he pushes on the 'multitude'. (Since the interpretation of this passage is a difficult, highly controversial matter, the reader is urged to consult strong defenses of the contrary view by Irwin, PMT (cf. n. 1), chapter 4, and by J. C. B. Gosling and C. C. W. Taylor, The Greeks on pleasure (1982), chapters 2 and 3.)

23. The nature of this antithesis seems to be misunderstood when it is argued (so Gosling and Taylor, Greeks on Pleasure 62-64) that the sentiment voiced by Socrates in the $A p$. and the $C r$. that dying should be preferred to living unjustly is not inconsistent with hedonism, since Socrates could have maintained (however implausibly) that the preference is justifiable on hedonistic grounds. This misses the point that for Socrates the very question of justifying the preference for a just to an unjust alternative by their respective yield in hedonic value is excluded $a b$ initio, for he holds that in such a matter no value whatever accruing to the unjust option should be considered at all: cf. T10, T11, T12, to be discussed below.

24. In the essay cited in $\mathbf{n} .17$ above and in several other essays in the same volume; also in his Inaugural Lecture, Duty and Interest (1928).

25. He wrote: 'morality for [Aristotle] consists in doing certain actions not because we see them to be right in themselves but because we see them to be such as will bring us nearer to the "good for man"" (Aristotle 188). To get truth instead of falsehood from this statement delete 'not' and substitute 'and' for 'but'.

26. I am indebted to $\mathrm{Mr} \mathrm{J}$. O. Urmson for bringing this extremely important passage to my attention.

27. Aristotle 15. For a reasonable defense of the 'substantial authenticity of the Magna Moralia and its importance for the study of Aristotle's moral philosophy' see John Cooper, 'The Magna Moralia and Aristotle's moral philosophy', AJP (1973) 327-49.

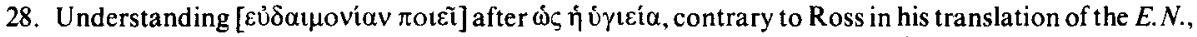

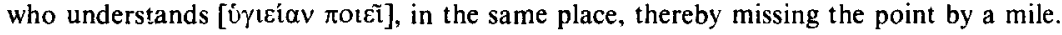

29. I have followed I. Bywater's text of the E.N. (1894).

30. J. A. Stewart, Notes on the Nicomachean Ethics (1892) II 98.

31. L. H. G. Greenwood, Aristotle's Nicomachean Ethics; Book VI (1909) 48.

32. For this ('inclusive') conception of happiness in Aristotle see especially J. Ackrill, 'Aristotle on Eudaimonia', PBA 60 (1974) 339-60.

33. See the long list of 'parts' of happiness in the Rhetoric (1360bl9ff.) That several of these items may be desired for the sake of other things is no objection to reckoning them 'parts' of happiness when desired for their own sake. 
34. Plato's Phaedo 59b8. Xenophon, Mem. 3.17 ('...Apollodorus and Antisthenes never leave me,'says Socrates to Theodote) and Simp. passim.

35. It was the view of the founders, Zeno and Chrysippus, and of leading Stoics thereafter that 'virtue is self-sufficient for happiness' (Diogenes Laertius 7.127), ensuring all by itself happiness at the maximum,

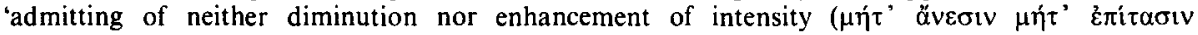
$\dot{\varepsilon} \pi 1 \delta \varepsilon \dot{\varepsilon} \varepsilon \sigma \vartheta \alpha 1$ )', (ibid. 101). Everything else ('life, health, pleasure, beauty, strength, wealth, good repute, high birth' and the like) they considered 'not goods [i.e. constituents of happiness], but

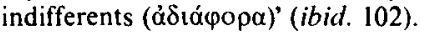

36. Sextus Empiricus quotes the saying twice (P. Hyp. 3.181; Adv. Math. 11.73) without naming its source.

37. No notice of them is taken in either of the great landmarks of nineteenth century Socratic scholarship: Eduard Zeller, Philosophie der Griechen; George Grote, Plato and the other companions of Socrates. They continue to be generally ignored in the present century. Thus they do not figure in the index locorum of the two book-length accounts of Socrates in the 'sixties: Norman Gulley, The philosophy' of Socrates (1968); W. K. C. Guthrie, History' of Greek philosophy' III (1969).

38. James Riddell, The Apology of Plato (1867) 66 and 167.

39. For the recognition of $\mathrm{T} 10$ and $\mathrm{T} 11$ as enunciating a 'principle of choice [A1], or at any rate, a principle that tells us what sorts of things to consider in making a choice', and of TII as doing the same [A2], thereby explaining momentous personal decisions made by Socrates throughout his life, see Santas, Socrates (1979) 32-33. In the present paper I show how AI and A2 in Santas are variant expression of a general principle of practical choice which is reiterated in the $C r$. (48c6-d5 $=\mathrm{T} 12$ below), where it is derived from a thesis concerning the relation of virtue to happiness (T15 below) which entails, either directly or through that principle, the absolute interdicts on $\dot{\alpha} \delta 1 \kappa \varepsilon \bar{\tau} v, \dot{\alpha} v \tau \alpha \delta 1 \kappa \varepsilon \tilde{\mathrm{i}} v, \dot{\alpha} v \tau 1 \kappa \alpha \kappa o v \rho \gamma \varepsilon \bar{\varepsilon} v$.

40. Cf. n. 6 .

41. For my understanding of the moral import of this play I am indebted to Martha Nussbaum, 'Consequences and character in Sophocles' Philoctetes', Philosophy and Literature 1 (1976-7) 25-53 and, even more, to a still unpublished study by Mary Whitlock Blundell, 'Ethical problems in Greek tragedy: Sophocles' Philoctetes' (1982).

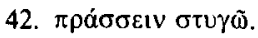

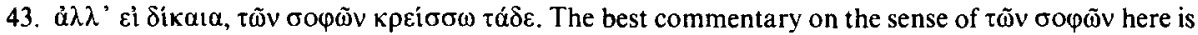
the dialogue at 100-120, where the course of action which is plainly dishonest and is recognized as

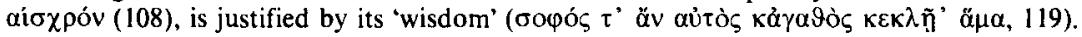

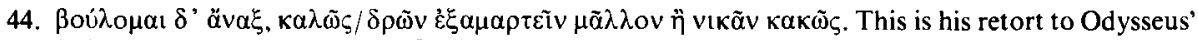

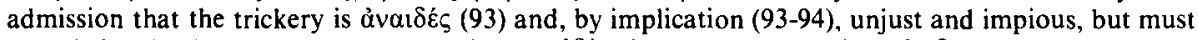

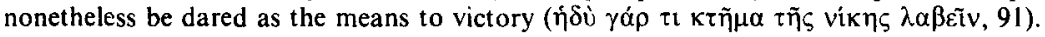

45. I am not suggesting that Isocrates adhered consistently to this noble sentiment. I see no defense against the blistering critique in the essay on Isocrates by Norman $\mathrm{H}$. Baynes in his Bl'zantine studies and other essal's (1955).

46. 'Ap aaloyvwoía (1981) 301-24, especially at 318-23. However, readers of that paper might wish to bear in mind that my account (in Section III of that paper) of Socrates' view of the relation of happiness to virtue calls for correction in the light of the present paper: I had assumed uncritically that Socrates is committed to what I shall be calling here the 'Identity Thesis'. I want to acknowledge my debt to colleagues at St Andrews (most particularly to lan Kidd) who commented on that earlier paper (its 
substance formed the first of my Gifford Lectures in that university in 1981); their discomfort with the Identity Thesis helped me to recognize that some revision of it was necessary, thereby leading me to move in the direction of the clear-cut alternative, adumbrated in a subsequent lecture at $\mathrm{St}$ Andrews, for which I argue systematically in Section $V$ of the present paper. I must also acknowledge my debt to Terence Irwin; having read that earlier paper, he pointed out to me that the mathematical model I use there is strictly inconsistent with the Identity Thesis: if virtue is the only component of happiness, then the use of the analogy of infinite to finite quantities to elucidate the relation of moral to non-moral goods becomes inapplicable, since on that hypothesis the latter will have zero value.

47. The way oủ $\alpha \mu \tilde{\omega} \varsigma \grave{\alpha} \delta 1 \kappa \varepsilon \tilde{\varepsilon} v$ is in fact derived in the text exhibits it (as I have pointed out in the paper cited in the preceding note, 309-310) as an entailment of previous agreements (49a5-6) that $\alpha \delta$ เ árałóv (49a6), is always KaKóv for the agent (49b5-7), which would also entail the principle of the Sovereignty of Virtue (and could have been used to derive the latter, had they preceded it in the text), and are themselves interentailing with the statement $(49 b 8-9=T 15)$ from which the Sovereignty of Virtue is derived in the text (as I proceed to explain in the following paragraph above). These expository

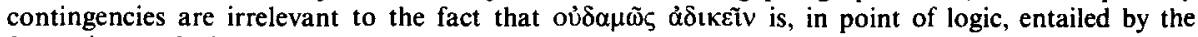
Sovereignty of Virtue and could be derived from the latter.

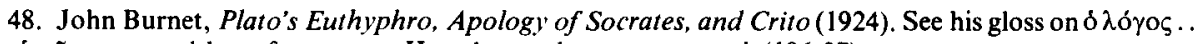
aip\&i supported by references to Herodotus, the orators, et al. (196-97).

49. The only reference to it in Gosling and Taylor (Greeks on Pleasure) is at 45 , where it is not connected with T12 and is explained away as 'vacillation'. On the interpretation I am presenting here there is no need to so regard it: T15 fits into a stably coherent moral theory.

50. Cf. n. 37 .

51. Presumably for this reason: I can think of no other to explain why so many scholars who were thoroughly familiar with this text should have made nothing of it. Why else, for instance, should $\mathrm{H}$. Maier, Sokrates (1913) contending mightily for an anti-utilitarian construction of Socratic eudaemonism ('die Tügend an sich selbst schon - night Glück bringt, sondern - Glück ist' 319) should cite $(317 \mathrm{n}$. 2) the first half of T15 and cut off the quotation at $48 \mathrm{~b} 6$, forfeiting that part of the text which, properly understood, would have given the very strongest backing to his interpretation?

52. One's whole interpretation of Socrates' moral theory could be altered by taking notice of the true import of this crucial text. Thus W. K. C. Guthrie, who does not cite T15 (or T10, T11, T12), would not have written, 'The utilitarian conception of good is certainly Socratic' (History of Greek Philosophy III. 463); William Frankena, Ethics (1963) 3-5 and 16, who ignores T15 in his extended account of $\mathrm{Cr}$. 47c-

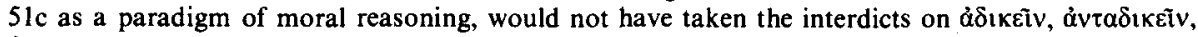

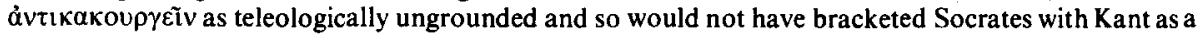
'rule-deontologist'. Both of these diametrically opposite misinterpretations of Socratic ethics could have been blocked if the role of T15 in its passage had been properly understood.

53. In view of the fact that the eudaemonist principle is not stated in the Cr., or indeed in any of Plato's Socratic dialogues prior to the $G$. (T22 below), objection may be taken to my use of it to elucidate the reasoning in the $\mathrm{Cr}$. I would reply that there is no need to suppose that Plato feels constrained to articulate in any given dialogue all of the major assumptions which govern the reasoning in that dialogue - least of all in the $\mathrm{Cr}$. which is conspicuously elliptical in its exposition of Socratic teaching, using the device of off-stage agreements (notably at $49 \mathrm{ab}$, "have we not frequently agreed in times past ...') to simplify the argument, licensing Plato to leave unmentioned premises which are incontestably common ground as between Socrates and Crito. (When a proposition is part of the uncontroversial consensus Plato may feel free to leave it unmentioned throughout the Socratic dialogues: so, certainly, the assumption to which I call attention in $\mathrm{n} .14, s c$. that for any given person that person's own happiness is, exclusively, of ultimate concern - a proposition which strikes the modern reader as contestable in the extreme.) 
54. To avoid the implication Socrates would have had to believe that the bond between virtue and happiness is purely instrumental, i.e. that the two are entirely distinct and are only causally connected. But if this were his view the all-important question, 'What then is happiness?' would draw a blank: the composition of happiness, which every Greek moral theory undertakes to specify - as pleasure in position (1) above, virtue in position (3), the exercise of virtue and intelligence along with a variety of subordinate goods in position (2) - would be left mysteriously indeterminate. This, I now feel, is the gravest flaw in the instrumentalist interpretation of Socrates' moral theory in chapter III of Irwin's brilliant book, $P M T$. Elsewhere I have contested that interpretation on other grounds (see my review in the Times Literary Supplement, Feb. 24, 1978, and subsequent exchanges in the correspondence columns of the journal: April 21, June 9, July 14, Sept. 27). Here I content myself with pointing out that the interpretation is predicated on the assumption that if Socrates holds (as he unquestionably does) that virtue is desirable for the sake of happiness, he cannot hold that it is also desirable for its own sake. Irwin sees very clearly how mistaken were the Oxford moralists who imputed that assumption to Plato and to Aristotle, but believes that there is textual evidence for imputing it to Socrates just the same. As I shall argue below (nn. 80, 98) there is no such evidence.

55. This feature of the model (entailing that the value of all non-moral goods would be conditioned on their conjunction with virtue) suffices to distinguish it from the counterpart Aristotelian conception of happiness (where e.g. health is good, so far as it goes, for all persons, regardless of their moral character). It would also suffice to distinguish it from the doctrine of Antiochus of Ascalon (ap. Cicero, De Fin. 5.78ff., Tusc, 5.22-23) which matches the model in allowing that virtue suffices for a 'happy' life, but not for the 'happiest' (beatam . neque tamen beatissimam, Tusc. 5. 22), maintaining (against the Stoics: cf. n. 35 above) that happiness admits of degrees (De Fin. 5.84), allowing that nonmoral evils are decremental (though the decrements are very small: exigua et paene minima, De Fin. 5.78); but there is no indication that Antiochus makes non-moral goods incremental only when conjoined with virlue, stipulating that virtue is a necessary condition of non-moral goods having any value whatever for their possessor, as does the model above.

56. A virtuous person would be happy, regardless of possession of non-moral goods, but happier with than without one or more of them (at a level higher than the minimal needed for the exercise of knowledge, below which virtue itself would be impossible and life would not be worth living: cf. n. 62 below). We know that Socrates believes that a man who is unhappy (because he acts unjustly) will be

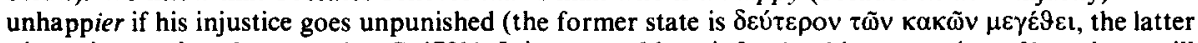
$\mu \dot{\varepsilon} \gamma(\sigma \tau o ́ v \tau \varepsilon \kappa \alpha \grave{i} \pi \rho \tilde{\omega} \tau o v \kappa \alpha \kappa \tilde{\omega} \nu, G .479 \mathrm{~b}$ ). It is reasonable to infer that his conception of happiness will similarly admit of degrees: good and evil, straightforward contraries, could hardly fail to be symmetrical in this important respect. To be sure, as Malcolm Schofield has pointed out to me, the variations in happiness in $G .479 \mathrm{~b}$ are correlated with moral differences (the "second" degree there corresponds to the state in which vice has been chastened by punishment). So the case for allowing Socrates that doctrine must rest, in the last analysis, on declining to impute to him the mulish adherence to preconceived dogma which it would take to maintain, in the face of all experience, that e.g. a virtuous man who has been suffering agonies from sciatica would be no thappier if he were freed from that excruciating torment without impairment of virtue (as the Stoics believed: cf. $n$. 35 above).

57. This model will allow for a low-grade morality of prudence in which pleasure could serve as the measure of the relative value of non-moral goods in abstraction from moral ones, thus providing a limited use of the 'measuring art' of Pr. 356e-357a. As I have pointed out elsewhere ('Socrates on acrasia', Phoenix (1969) 71-88: a paper much in need of revision at some other points), all of the examples in the debate with the men of 'the multitude' involve exclusively non-moral goods (health, wealth, national power $353 \mathrm{c}-354 \mathrm{~b})$ : the hedonistic equation, 'good=pleasant', is effected by suppressing all moral

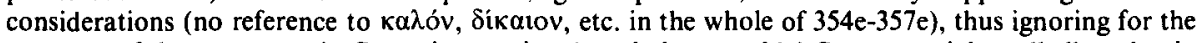
purposes of the argument the Socratic equation, 'good=honourable'. Socrates might well allow that in those cases in which the latter equation offers no guidance for choice (because we are confronting alternatives which are equally consistent with virtue) the issue is legitimately decidable on the basis of hedonic values. (Later in the debate the second equation is grafted on the first by ad hoc agreement [358b3-5] and the graft is used at 359e - ironically, in my opinion - to show Protagoras that he must 
regard all honourable actions as pleasant and therefore regard the brave man's preference for wounds or death in combat to flight as hedonistically justifiable [contrast $G .498 \mathrm{a} 5-498 \mathrm{e}$ ].) In elucidating 354a$357 \mathrm{e}$ we should be on our guard against reading the lofty connotations of 'salvation' triggered by so translating (unavoidably, no doubt) such spurious evocations we might compare the sea-captain who 'saves' his passengers, the general who

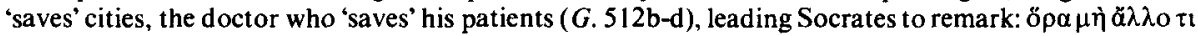

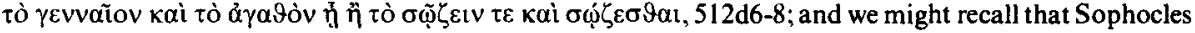
makes Odysseus invoke 'salvation' to justify the low trick on Philoctetes:

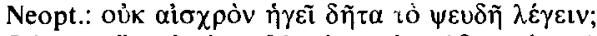

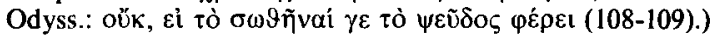

58. This should not be confused with the standard Stoic doctrine that 'virtue is self-sufficient for happiness' by which they understand precisely what I am calling 'the Identity Thesis', that virtue is the only component of happiness, the only good (cf. $n$. 35 above). Still less should it be confused with what Irwin calls 'the sufficiency of virtue' (PMT 100-101) which stands at the other extreme from both the Stoic view and also from what the Socratic view would be on either the Identity or the Sufficiency Theses, since Irwin takes the relation of virtue to happiness to be instrumental (cf. n. 54 above) while I take it to be strictly constitutive on both the Stoic and the Socratic views.

59. Topics 103a23-31, b10-12.

60. His third, 'accidental sameness', is irrelevant to the analysis of T15.

61. $\dot{\alpha} v \tau \iota \kappa \alpha \tau \eta \gamma о \rho \varepsilon \tau \tau \alpha$, i.e. that for all $x, x$ has $A$ if, and only if, $x$ has $B$.

62. That is to say, at a level higher than that strictly necessary to sustain virtue: If health fell below a certain minimal level $x$ 's mental processes would fail - he would be incapacitated for the exercise of knowledge and therewith for that of virtue, since Socrates holds that virtue 'is' knowledge. (We may surmise that some such sub-minimal physical state is what Socrates has in view at $C r$. 47d-e and G. 512a: a body so ravaged by disease that life is no longer preferable to death.) Mutatis mutandis the same would be true of 'wealth', i.e. of the means of subsistence.

63. I am not crediting Socrates with anticipating the Aristotelian analysis of the various senses of 'the same' - far from it: had he done so he would have saved himself a pack of trouble (cf. Platonic Studies 2 (1981) 431-33 and 444-45). I invoke the Aristotelian analysis to show that a student of multivocity (which, alas, Socrates was not) attests a use of 'the same' which is the only one that fits T15 (since neither homonymy, nor definitional identity, nor accidental identity will). In T2l(b) and then again, more elaborately, in T22 below we shall see Socrates use interentailment to express the relation of virtue to happiness, doing so without resort to any word suggestive of identity in that context, while continuing to

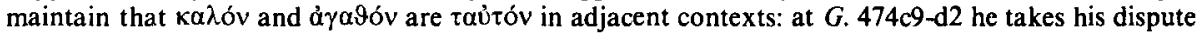
with Polus to pivot on the latter's denial of this proposition.

64. And note that the Identity Thesis is not suggested at all in the statements at $49 \mathrm{a} 5-6$ and $49 \mathrm{~b} 4-6$ which (as I remarked above: n. 47) "also entail the principle of the Sovereignty of Virtue (and could have been

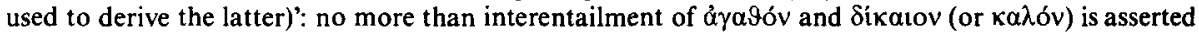

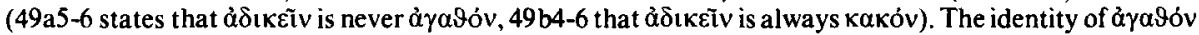

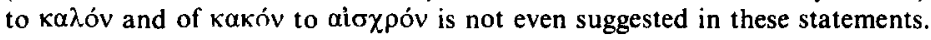

65. This is Epictetus' favourite Socratic text. He cites it repeatedly (always in the same pungent paraphrase: 'Anytus and Meletus can kill me but cannot harm me'): Diss. $1.29 .17 ; 2.2 .15 ; 3.23 .21$.

66. I am adopting Burnet's construction of the terminal clause (' $\alpha \gamma \alpha \circlearrowleft \alpha$ is predicate', ad loc.) (n. 48) which has been ignored in every subsequent translation known to me except Robin's in the Pléiade Plato I (1956) where the same construction is being followed (without argument, without reference to Burnet 
and without appeal to his suggested syntax). For a rejection of the traditional translation (even without opting for Burnet's syntax) and an alternative suggestion for avoiding its perverse reading of the text (it makes Socrates recommend virtue as a money-maker) see Myles Burnyeat, 'Virtues in action', in The philosophy of Socrates, ed. by G. Vlastos (1971) 209-234 at 210.

67. Cf. Ch. 156e6-9 ('all good and all evil, whether in the body or in the whole man, comes from [the condition of] the soul'); $\operatorname{Pr} .313 \mathrm{a} 7-8$ ('the soul, on whose deterioration or improvement your whole welfare depends').

68. Or, perhaps, 'by comparison with the value I attach to our friendship'.

69. Cf. the use of negation at $A p$. 23a: Socrates takes the god to be declaring that human wisdom is 'worth little or nothing'; that 'nothing' is a disguised comparative becomes clear in the sequel (b2-4): the

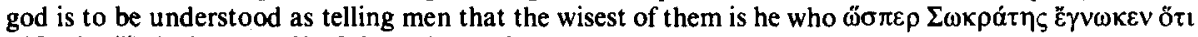

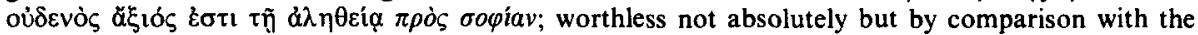
superlative wisdom of the god.

70. The alternative translation, 'does all of happiness consist in that?' is possible (so Robin, n. 66, and Santas in his Socrates 266) but improbable in view of the plethora of passages which attest the wide use of the $\dot{\varepsilon} \vee \tau \tilde{\varphi}$. . ż $\sigma i v$ phrase to mean 'depends on' or 'rests in': Soph. O.T. 314, O.C. 248; Eur. Alc. 278; Thuc. 1.74.1 and 3.13.5; Plato, Pr. 354e7; Dem. 18.193 (I am indebted to T. Irwin for the first three references, to lan Kidd for the rest). To opt for the latter translation is not to give hostages to the instrumentalist interpretation of the Socratic theory: the dependence could be constitutive (i.e. entailment, not causal consequence); the issue remains open, to be decided on other grounds: cf. n. 54 above).

71. This is how the Stoics read T21. Cicero's (Tusc. 5.35) gloss on Polus' last question is, 'Videtur omnem hic beatam vitam in una virtute ponere?'

72. And similarly in G. 507d6-el: 'This, I do believe, is the mark ( $\sigma \kappa \circ \pi \circ \zeta$ ) to which one should look throughout one's life, that everything in one and in one's city should tend to the presence of justice and temperance in one who is to be blessed', where 'everything' raises the same question as does 'all' in T21 above: does Socrates mean that virtue is our only good or, rather, the all-important one which should have absolute priority over all of our other goods, since it is the condition of the goodness of anything else?

73. Or that 'happiness is nothing but virtue' or, as in Cicero's gloss (n. 71), 'happiness rests solely in virtue'.

74. Any of these texts, read without the correction for which I have argued above, would amply suffice to make the Stoics believe that their view of the 'all-sufficiency of virtue' (cf. $n .50$ above) was pukka Socratic. Cf. n. 65 and n. 71.

75. The target could be Antisthenes. If it was Socrates we could not infer that the Identity Thesis is being imputed to him. The Sufficiency Thesis could have provoked the same objection.

76. Cf. n. 19 above.

77. Would this objection tell also against the Stoic view (cf. n. 35 above)? This had a doctrine of natural elective affinity (oikei $\omega \sigma(\zeta)$ for life, health, etc., which makes such things naturally oikeid to us and,

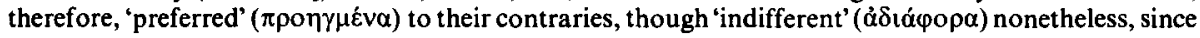
they are not goods. But does it really make sense of say that life, health, etc. are 'preferred' and 'indifferent"? Unable to pursue this question within the limits of the present essay, I still venture to suggest that the multicomponent model of happiness I have sketched for Socrates here would have served the Stoics better than anything on their market, including the doctrine of Antiochus (cf. n. 55 
above): it would have enabled them to hold that their $\pi \rho \circ \gamma \gamma \mu \varepsilon v \alpha$ are goods without jeopardizing their concern that virtue be both necessary and sufficient for happiness.

78. I argued above (second paragraph of Section III) for this function of TIS. For that purpose the Identity Thesis is postulational over-kill.

79. I.e. constituents of the good, as is shown by the interchangeability of 'goods' with 'good' throughout the passage: Socrates uses the plural to refer disjunctively to the same things to which he refers conjunctively by the singular.

80. He expresses this clumsily by saying that in the case of such actions 'we want that for whose sake we do them, but we do not want them' $(468 \mathrm{~b} 9-\mathrm{cl})$. The italicized phrase is clearly false (if I choose to submit to painful medical treatment I most certainly do want it though, no less certainly, I do not want it for its own sake) and Socrates is rightly criticized for it by Irwin, Plato's Gorgias (1979) 141, who, however, infers that Socrates is endorsing a further proposition - the thesis that we can never want anything both for its own sake and for the sake of something else. Pace Irwin (and other commentators: this reading of the passage is common), Socrates does not commit himself to this thesis here (or anywhere else: $c f . n .98$ below). When he declares at 467d6-el that if we do $x$ for the sake of $y$ we do not want $x$ but $y$, the first variable ranges over things of the sort he has identified just before (476c7-d5) by example (medical treatment, business ventures) and will proceed forthwith to categorize as 'intermediates'. When he reiterates the declaration at $468 \mathrm{~b} 7-8$ its scope is similarly restricted by his examples: he starts off, 'Have

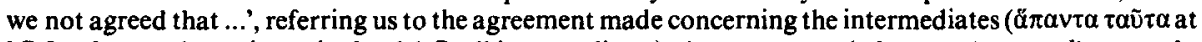
b7-8 refers to the actions cited at b1-7, all intermediates). Agreement on 'whatever intermediates we do for the sake of something, we do not want them' does not entail 'whatever goods we do for the sake of something, we do not want them', which Socrates would have no more reason to grant than would Aristotle (cf. T7 above) or Plato (cf. the reference to $R .2,357 \mathrm{~b}-358 \mathrm{a}$ at 183 above).

81. The great argument against Polus and Callicles that to suffer wrong is always better than to commit it turns on that principle. It is implied in 507d6-el (cited in $\mathrm{n} .71$ above).

82. It should not be supposed that the application of this criterion would be superfluous if the former had been met: two courses of action of unequally healthful quality might nonetheless be both acceptably temperate.

83. Before being attacked ( $89 \mathrm{cff}$.) and finally rejected (96d-98c) in favour of the unSocratic thesis that for the right guidance of action true belief is as good as knowledge. I take the initial defense of the Socratic thesis to represent the point of view maintained throughout the Socratic dialogues, the subsequent attack on it to present the new position which Plato will be putting into Socrates' mouth in the middle dialogues.

84. The reference is to the non-moral goods which head the list of goods at $279 \mathrm{a}-\mathrm{b}$ and return in great style at $281 \mathrm{c} 3-\mathrm{d} 1$ to illustrate the point which is being made here that when goods are misused they are sources of unhappiness. It might appear that the indictment of non-moral goods on this score would also extend to moral ones (courage and temperance appear as examples at $281 \mathrm{c} 6$, sand wiched in between two sets of non-moral goods.) But a moment's reflection should show that the control by ignorance of attributes whose very essence is wisdom is a counter-factual: if (per impossibile) courage and temperance could be controlled by ignorance (as all of those non-moral qualities in the list obviously can), then they too would be a blot on our happiness. In the doublet of this passage in the $M$. (88a6-d3) the counter-

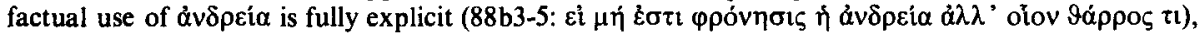
indicating that $\sigma \omega \varphi \rho 0 \sigma u ́ v \eta$ too (b6) should be understood in the same way. Cf. Irwin PMT52 and 29596 , n. 16.

85. Or, perhaps, 'by themselves alone.' I take $\kappa a \vartheta$ ' $\alpha$ í d to mean 'by themselves' (so L. Méridier in his transl. of the Eud.: Platon: Oeuvres Complètes V.1 (1956), and L. Robin in the Pléiade Plato: "par eux- 


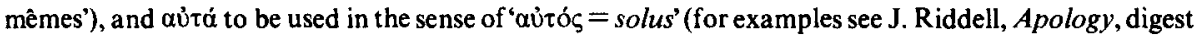

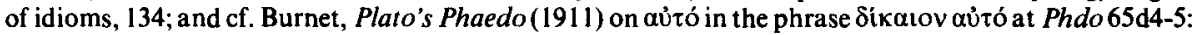

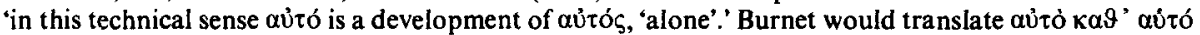

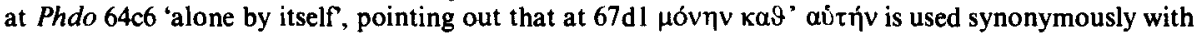

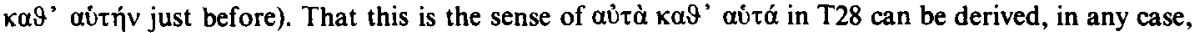
directly from the context: the denial that the non-moral goods are $\alpha \dot{v} \tau \dot{\alpha} \alpha \alpha \vartheta^{\prime}$ a $\operatorname{cod}^{\prime} \alpha \gamma \alpha \vartheta \dot{\alpha}$ brings to a head the thesis (profusely illustrated by examples) that 'without wisdom there is no benefit in any possession' (281 b5-6), i.e. detriment, instead of benefit, in any good used in isolation from wisdom. So too in the $M$. doublet, where the same thesis is argued for, announced at $87 \mathrm{~d} 5$, that nothing is good

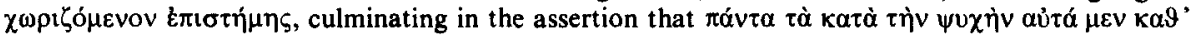

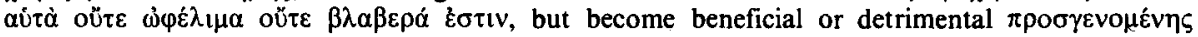

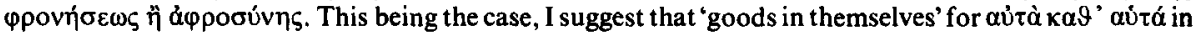
T28 (so in the Jowett translation and in Irwin's paraphrases of the passage in $P M T 32$ ) is questionable: it builds into the translation the contestable claim that Plato uses the phrase to assert that the value of nonmoral goods is merely instrumental (rather than contingent, i.e. conditional on their right use under the guidance of wisdom).

86. Cf. n. 94 below.

87. Same thing in the $M$. doublet (87e-88a).

88. Socrates is so understood by Donald Zeyl, 'Socratic Virtue and Happiness', Arch. für gesch. der Philos. 64 (1982) 225-38 at 231: the non-moral goods are 'effectively transferred [at T27] to the status of "neutrals" [ = intermediates] in the Gorgias'. He is apparently unaware of the resulting inconsistency 1 am pointing out above. (I regret that I failed to point this out to him when I read his paper prior to its publication: at that time I was still confused on this point myself.)

89. There is nothing new in this account of the content of the passage; if there is any difference from the standard accounts (like that of A. E. Taylor, Plato, the man and his work (1949) 94) it is verbal. What is new is the insistence that to get this content from it we must supply the proposed expansion, for otherwise the passage will flout the categorial scheme established in the $G$., and the Socratic view will then collapse into the position which will be taken up later by the Stoics: '...they [Chrysippus et al.] say that what may be used both well and ill is not good: wealth and health can be used well and ill; hence wealth and health are not good (Diogenes Laertius 7.103; cf. Sextus, Adv. Math. 11.61). Without the proposed expansion of the italicized phrase in T27(b) Socrates too would be saying with the Stoics that health is not good (hence indifferent) and disease is not evil (but indifferent). Commentators who represent him as teaching in T28 that everything except wisdom and ignorance is neither good nor evil seem unaware of the far-reaching consequences for his whole conception of the relation of virtue to happiness if he were to assert in good earnest, like the Stoics, that health, wealth, etc. are not good. See e.g. how Io.von Arnim, in his account of the Socratic position in the Eud., Platos Jugenddialoge (1914) 126 , slides from 'an und für sich ... sind sowohl sie [health, wealth, etc.] wie ihre évavtía gänzlich wertlos'

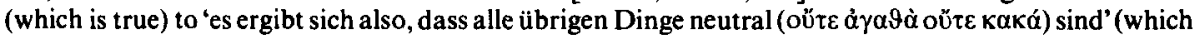
is false).

90. While otherwise it would not. From ' $x$ is $F$ only in conjunction with $W$ ' it would be crazy to infer ' $x$ is not $F$. The sober inference from that premise would be ' $x$ is not $F$ in disjunction from $W$, i.e. ' $x$ is not $F$ just by itself.

91. I must emphasize that there is nothing in the least shaky in the notion of conditional constituents of happiness, i.e. of things which are indeed desirable for their own sake, but only when certain additional conditions are fulfilled.

92. Once this conclusion has been reached about occurrences of the problematic phrase in T28(b) it will dictate the same reading of two further occurrences of it later on (292b-d): the remark about non-moral

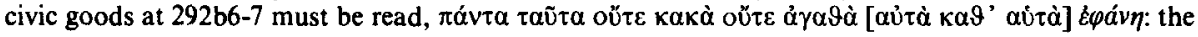


back reference to T28, effected by the word 1 have italicized, is an essential guide to the meaning; it assures us that what is being said here is hung on what was said there and consequently requires the same interpretation. The reference to 'neither evil nor good' which follows at 292d2-3 must be understood in the same way. For confirmation we may note that in the doublet of T28 in the $M$. the observation that non-moral goods are beneficial when rightly used, detrimental when ill used, does not lead to the conclusion that they are neither beneficial nor detrimental but that they are neither the one nor the other

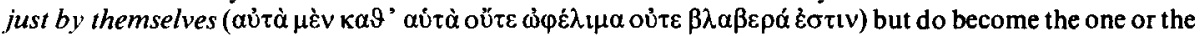
other when 'conjoined to wisdom or ignorance'.

93. Same reasoning as in Plato (T6 above) and Aristotle (E.N. 1093a20-21).

94. Sometimes designated by 'wisdom' (as in T28), standing by synecdoche for all of Socrates' canonical virtues, whose essence it is.

95. There is no mystery about the fact that it goes unmentioned in the $\pi \rho \tilde{\omega} \tau o v$ qi $\lambda$ ov passage whose purpose is to establish the necessity of a final object of desire, not to give an exhaustive account of nonfinal ones.

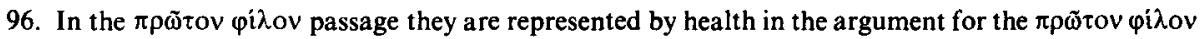
$(219 c-d)$, by the boy's life the father is desperately anxious to save in the sequel (219d-e).

97. These are Plato's class-(c) goods in $R .2,358 \mathrm{c}-\mathrm{d}$ (cf. Section II above). In the $L y$. they are represented by medical treatment (219c) and by all those things (money, the wine, the container) which are so utterly expendable for the sake of the boy's life, non-moral good though this is (219d-220a).

98. When Socrates warns in the $\pi \rho \tilde{\tau} \tau o v$ $\varphi$ i $\lambda$ ov passage $(219 \mathrm{~d} 2-4)$ that we should not be deceived by 'all those other things which we said were dear for its sake [sc. that of the $\pi \rho \tilde{\omega} \tau o v$ qí $\lambda \circ v$ ], images of it, as it were' (d2-4), it is tempting to take him to be warning that anything which is dear for the sake of the $\pi \rho \tilde{\tau}$ กv $\varphi$ i $\lambda$ ov (hence moral goods no less than non-moral goods and intermediates) may so deceive us. We should resist the temptation, reflecting on how absurd it would be for Socrates to say that moral virtue (which 'is' wisdom) should deceive us, and noting that nothing in $\mathrm{d} 2-4$ requires this (pace Irwin, $P M T 85)$, for moral goods did not figure in that antecedent passage $(219 \mathrm{cl}-\mathrm{d} 2)$ to which 'we said' at d3 refers: only items in categories III and IV were mentioned and it would be unwarranted to generalize from these to items in category II - as much so as it would be to generalize from intermediates to goods in T25 (cf. n. 75 above). The same temptation must be resisted at 200a 7-b3: 'those things which we say are dear to us for the sake of something else seem to be dear only in a manner of speaking, while really dear is that very thing in which all those affections terminate.' If the last clause were allowed unrestricted generality (so Irwin, $P M T 85$ ), it would carry the same implication as before, i.e. that moral goods, no less than other things, are not themselves 'really dear'. But nothing was said in the lines preceding a7 (from which the quoted statement is inferred: this is the force of $\gamma \dot{\alpha} \rho$ at $220 \mathrm{a} 7$ ) to commit Socrates to holding that not only items in categories III and IV (the only ones figuring in the examples from which he is generalizing), i.e. things which are either contingently good or intermediate, but items in category II as well, which are invariably and necessarily good, are 'dear only in a manner of speaking'. If we heed this caution we shall not follow Irwin, who infers from the present passage in the $L y$. that Socrates holds that if we choose something for the sake of something else we cannot also choose it for its own sake.

99. Shorter versions of this paper were read to the Cambridge Philological Society, to my Cambridge seminar on Socrates (Michaelmas Term, 1983), and to the Conference on the History of Ethics held at the University of California at Irvine (January, 1984). Earlier versions of parts of it were tried out in seminars at Berkeley and Toronto and at a colloquium at Princeton. One version formed one of my Gifford Lectures at St Andrews. I acknowledge warmly my debt to those whose critical responses have shaped my thought. My heaviest debt, a long-standing one, is to Terence Irwin: his book has done more to clarify my thinking than anything $I$ have ever read on its topic. Extensive critical comments on the present paper from Terence Irwin, Ian Kidd and A. A. Long have led to corrections. Searching questions have also been given me by Myles Burnyeat, John Procopé, David Sedley and Gisela Striker. Persistent 
criticism of an earlier error from Alan Silverman has stimulated me to work my way out of a previous muddle - confusion of instrumental with conditional component goods. I must emphasize that none of those I have thanked may be presumed to agree with any of the views I have defended.

\section{BIBLIOGRAPHY}

J. Ackrill, Aristotle's Ethics (1973).

'Aristotle on Eudaimonia', PBA 60 (1974) 339-60.

Io. v. Arnim, Platos Jugenddialogen (1914).

N. B. Baynes, Byzantine Studies (1955).

Mary Whitlock Blundell, Ethical Problems in Greek Tragedy: Sophocles' Philoctetes (unpublished, 1983).

J. Burnet, Plato's Euthyphro, Apology of Socrates, and Crito (1924).

Plato's Phaedo (1911).

J. Cooper, 'The Magna Moralia and Aristotle's Moral Philosophy', AJP (1973) 327-49. Aristotle on Human Good (1975).

E. R. Dodds, Plato's GORGIAS (1959).

K. J. Dover, 'The Portrayal of Moral Evaluation in Greek Poetry', JHS (1983) 35-48.

J. Dybikowski, 'Is Aristotelian Eudaimonia Happiness?' Dialogue (1981) 185-200.

W. Frankena, Ethics (1963).

J. Gosling and C. C. W. Taylor, The Greeks on Pleasure (1982).

G. Grote, Plato and the Other Companions of Socrates 1 (1865).

L. H. G. Greenwood, Aristotle's Nicomachean Ethics (1909).

N. Gulley, The Philosophy of Socrates (1968).

D. Hume, Enquiry concerning the Principles of Morals (1977).

T. Irwin, Plato's Moral Theory 1 (1974). Plato's Gorgias (1979).

W. K. C. Guthrie, History of Greek Philosophy III (1969).

R. Kraut, 'Two Conceptions of Happiness', Philos. Review (1979) 167-97.

H. Maier, Sokrates (1913).

L. Méridier, translation of the Euthydemus in Platon: Oeuvres Completes, V.1 (1956).

Martha Nussbaum, 'Consequences and Character in Sophocles' Philoctetes', Philos. and Literature (1976-77) 25-53.

H. A. Prichard, Duty and Interest (1928). Moral Obligation (1949).

J. Riddell, The APOLOGY of Plato, with Digest of Platonic Idioms (1867).

L. Robin, Platon: Oeuvres Complètes I (1956).

W. D. Ross, Aristotle 1 (1923). Aristotle's Nicomachean Ethics (trans.) in W. D. Ross and J. A. Smith, The Works of Aristotle translated into English (1910-52).

G. Santas, Socrates (1979).

H. Sidgwick, Methods of Ethics 7 (1907).

J. A. Stewart, Notes on the Nicomachean Ethics (1892).

A. E. Taylor, Plato, the Man and his Work 6 (1949).

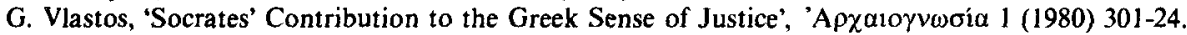
'Socrates on acrasia', Phoenix (1969) 71-88.

Review of T. Irwin, Plato's Moral Theory in Times Literary Supplement (1978) 230-31. Platonic Studies 2 (1981).

E. Zeller, Sokrates und die Sokratikers (1922).

D. Zeyl, 'Socrates and Hedonism - Pr. 351 b-358d', Phronesis (1980) 250-69.

'Socratic Virtue and Happiness', Arch. für Gesch. der Philos. 64 (1982) 225-38. 